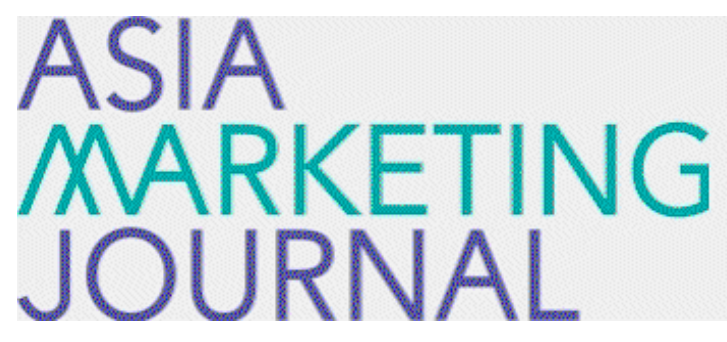

ASIA MARKETING JOURNAL

Volume 10 | Issue 3

Article 5

$10-30-2008$

\title{
LIG손해보험의 새로운 기업브랜드 전략을 통한 기업이미지 재정립
}

Kwang Ho Ahn

Chang Jo Yoo

Dong Hoon Kim

Follow this and additional works at: https://amj.kma.re.kr/journal

Part of the Marketing Commons

\section{Recommended Citation}

Ahn, Kwang Ho; Yoo, Chang Jo; and Kim, Dong Hoon (2008) "LIG손해보험의 새로 운 기업브랜드 전략을 톨 한 기업 이미지 재정립," Asia Marketing Journal: Vol. 10 : Iss. 3 , Article 5.

Available at: https://doi.org/10.53728/2765-6500.1222

This Article is brought to you for free and open access by Asia Marketing Journal. It has been accepted for inclusion in Asia Marketing Journal by an authorized editor of Asia Marketing Journal. 


\title{
LIG손해보험의 새로운 기업브랜드 전략을 통한 기업이미지 재정립
}

\author{
LIG Corporate Image Re-establishment \\ through New Corporate Image Strategy
}

\author{
안 광 호(Ahn, Kwangho)* \\ 유 창 조(Yoo, Changjo)** \\ 김 동 훈(Kim, Donghoon) $)^{* * * *}$
}

2006년 손해보험시장의 선도브랜드였던 LG화재는 LIG손해보험으로 기업브랜드명을 변경하면서 적 극적 사회공헌활동을 토대로 고객과 사회에 희망을 주는 일등보험금융그룹으로서의 기업이미지를 성 공적으로 구축하고 있다.

2004년에 실시되었던 기업브랜드에 대한 소비자조사 결과에서 LG화재는 경영성과에 대비하여 브 랜드파워가 상대적으로 낮게 형성되어 있는 것으로 나타나, 브랜드 경쟁력 강화를 위해 브랜드 자산 구축전략을 수립할 필요성이 대두되었다. 계열분리에 따라 LG화재는 새로운 기업브랜드 도입을 계획 하고, 중장기적인 기업브랜드 자산구축전략의 일환으로 2004년부터 기업브랜드교체를 위한 준비단계 에 돌입하였다. 일등보험금융그룹으로서의 규모감과 $\mathrm{LG}$ 의 계승/발전이라는 의미를 함께 담아 기존의 긍정적 이미지 자산이 전이될 수 있는 방향으로 $\mathrm{LG}$ 화재에 대한 기업브랜드 교체전략을 수립하고자 하였다.

LG화재는 LIG 손해보험이라는 새로운 기업 브랜드를 통해 '삶의 소중함을 함께 가꿔나가는 동반 자'로서 고객에게 보험의 새로운 가치를 제공하고자 하였다. 이를 위한 LG화재는 3가지 내부 공유가 치를 설정하였다. 먼저, LG화재 브랜드의 기업비전과 공유가치를 담은 “브랜드 지향가치”를 설정하 고, 브랜드 가치에 대한 소비자 공감을 획득하기 위해 “브랜드 전달가치”를 설정하고, 그리고 마케팅 커뮤니케이션을 통해 소비자 인식 속에 형성시키고자 하는 “목표이미지”를 설정하였다.

LG화재는 새로운 브랜드가치를 고객들에게 전달하기 위해, "LIG손해보험”이라는 새로운 기업브랜 드와 신규 하위브랜드를 개발하기로 했다. 또한 효과적인 기업브랜드 관리를 위해, 기업브랜드 목표 의 수립과 브랜드모니터링 기능을 한 부서에서 통합적으로 관리하도록 하였다. 또한 브랜드 자산구축 에 대한 목표관리를 위해 브랜드 측정모델을 개발하고 브랜드 평가에 활용하였다. LIG손해보험은 통

\footnotetext{
인하대학교 경영학과 교수(ahnkh@inha.ac.kr)

** 동국대학교 경영학과 교수(yoo@dongguk.edu)

*** 연세대학교 경영학과 교수(dhkim@yonsei.ac.kr)
} 
합적 브랜드 커뮤니케이션을 통해 목표 브랜드이미지를 소비자의 마음속에 심고자 노력했고, 그 결과 기업브랜드의 성공적 교체라는 목표를 실현할 수 있었다.

새로운 기업브랜드를 런칭한 이후, 2006년 5월에 실시한 온라인 서베이의 결과에서 LIG손해보험을 $\mathrm{LG}$ 화재의 새이름인 것으로 정확하게 인지하고 있는 경우가 $88.9 \%$ 로 나타나, 새로운 $\mathrm{CI}$ 를 성공적으 로 소비자들에게 인식시켰다는 평가를 받았다. LIG손해보험은 성공적으로 구축된 브랜드인지도를 바 탕으로, "고객과 사회에 희망을 주는 기업”이라는 기업 이미지를 정립하고자 한다. 이를 위해 LIG손 해보험은 '고객과 함께 성장하며 삶의 소중함을 가꿔나간다'라는 긍정적 브랜드-소비자관계를 구축할 수 있도록, 다양한 사회공헌사업을 계획/전개하고 있다.

핵심개념: 손해보험, 기업브랜드, 기업이미지, 브랜드 아이덴티티, 브랜드 아키텍처, 커뮤니케이션, $\mathrm{CI}$ (Corporate Identity), 사회공헌활동

\section{I. 서 론}

2000년 들어서면서 손해보험업의 경쟁구도가 고착화되어 갔다. 1991 년에 $16.7 \%$ 이던 삼성화 재의 시장점유율이 2003 년엔 $31.9 \%$ 로 증가하여 시장점유율 1 위의 자리에 오르게 되었으나, $\mathrm{LG}$ 화재는 2003년 시장점유율 13.7\%로서 1991년 대비 $1 \%$ 증가한 수준으로 시장확대에 어려움
을 격고 있는 상황이었다(〈그림 1〉참조). $\mathrm{LG}$ 화재가 확고한 2 위 자리를 굳히고, 나아가 1 위 를 달성하기 위해서는 새로운 돌파구 마련이 시급하다는 의견들이 제시되었다.

$\mathrm{LG}$ 화재가 영업 및 서비스 영역에서 2 위 달성 을 위한 확고한 기반을 마련해가고 있는 반면, 브랜드인지도의 파워를 반영하는 최초상기도는 시장점유율에 비해 낮게 형성되어 있어 브랜드 인지도 구축을 위한 적극적인 대응이 요구된다

〈그림 1〉 손해보험시장의 시장점유율 변화추이

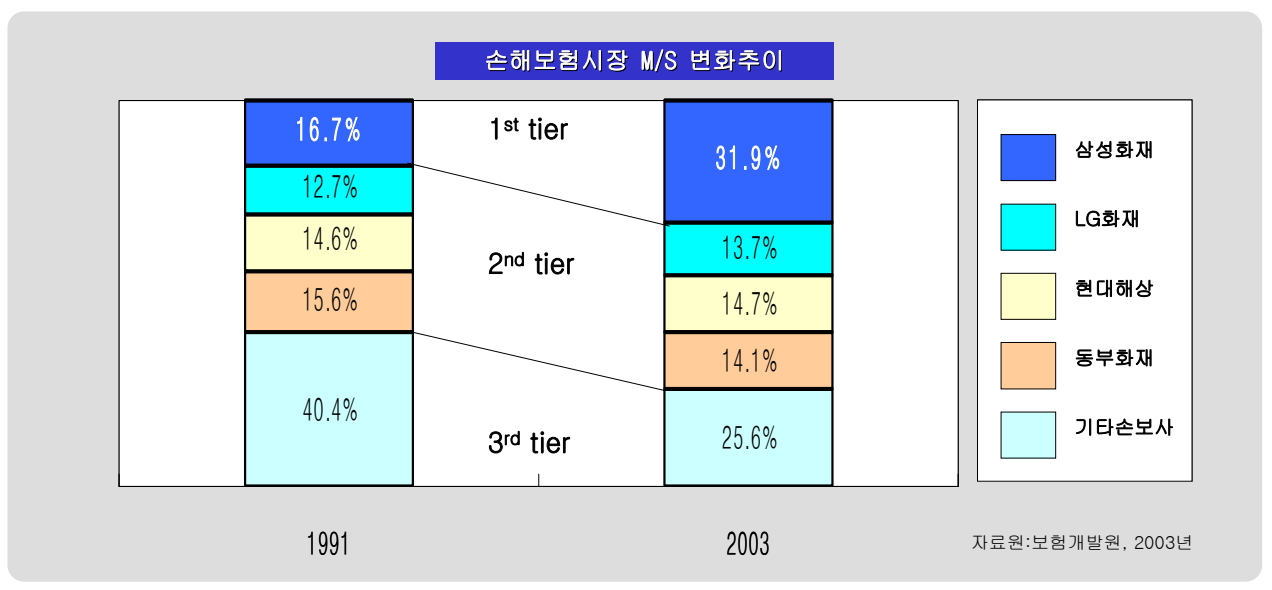


〈표 1〉 경쟁사와의 경쟁력 비교

\begin{tabular}{|c|c|c|c|}
\hline & $\begin{array}{c}\text { 영업조직 } \\
\text { (명) }\end{array}$ & $\begin{array}{c}\text { 보상조직 } \\
\text { (명) }\end{array}$ & $\begin{array}{c}\text { 가맹점 } \\
\text { (개) }\end{array}$ \\
\hline 삼성화재 & 32,274 & 1,785 & 600 \\
\hline 동부화재 & 16,271 & 1,002 & 553 \\
\hline 현대해상 & 14,798 & 1,030 & 565 \\
\hline LG화재 & 18,119 & 952 & 560 \\
\hline \multicolumn{4}{|c|}{$\begin{array}{l}\text { (쥐 1)자료원 : LG화재, 2004년 8월말 현재 } \\
\text { 2)자료원 : } L G \text { 화재, 2004년 7월말 현재 }\end{array}$} \\
\hline
\end{tabular}

\begin{tabular}{|c|c|c|c|c|}
\hline & \multicolumn{2}{|c|}{ 자동차보험 } & \multicolumn{2}{|c|}{ 장기보험 } \\
\hline & $\begin{array}{c}M / S^{2)} \\
(\%)\end{array}$ & $\begin{array}{c}\text { 최초 상기도) } \\
(\%)\end{array}$ & $\begin{array}{c}M / S^{2)} \\
(\%)\end{array}$ & $\begin{array}{c}\text { 최초 상기도 }{ }^{3)} \\
(\%)\end{array}$ \\
\hline 삼성화재 & 30.0 & 45.0 & 35.0 & 50.0 \\
\hline 동부화재 & 13.2 & 15.7 & 15.9 & 15.8 \\
\hline 현대해상 & 13.5 & 11.5 & 14.7 & 9.8 \\
\hline LG화재 & 12.0 & 10.8 & 14.7 & 8.2 \\
\hline
\end{tabular}

3)자료원 : B\&C, 소비자 정량조사, 2004년 7월

고 판단되었다. 〈표 1〉에 의하면, $\mathrm{LG}$ 화재의 자 II. 본 론 동차보험과 장기보험의 경우, 2004년 7월말 기 준으로 시장점유율이 각각 $12.0 \%$ 와 $14.7 \%$ 인 반면, 최초상기도는 각각 $10.8 \%$ 와 $8.2 \%$ 로 나 타나 시장점유율에 비해 낮은 수준임을 알 수 있다.

최초 브랜드상기도에서의 경쟁열위와 함께 2004년 12월말로 LG브랜드에 대한 사용기간이 만료되는 상황으로 인해 $\mathrm{LG}$ 화재는 기업브랜드 에 대한 전략적 결정이 필요하다는 인식을 갖 게 되었다. 1959년에 '범한해상’으로 출발하여 '럭키화재'라는 기업브랜드를 거쳐 40년이 넘도 록 화재보험업계에서 선도적 지위를 유지해왔 던 LG화재가 또 한번의 기업브랜드 변경이라 는 어려운 전략적 결정을 내리게 된 것이다.

이에 따라, $\mathrm{LG}$ 화재는 현재 기업브랜드의 기 회와 위협, 강/약점을 진단한 후, 새로운 브랜 드 아이덴티티 전략을 수립하고, 브랜드 아키텍 처를 설계하며, 새로운 기업브랜드가 성공적으 로 정착할 수 있는 마케팅커뮤니케이션 전략을 구상하였다.

\section{1 브랜드 진단}

과거에는 $\mathrm{LG}$ 그룹 차원의 전략이나 상황에 따 라 $\mathrm{CI}$ 를 교체하여 왔으나, $\mathrm{LG}$ 브랜드의 사용기 간 만료를 앞둔 2004년 시점에서는 보다 중장 기적인 브랜드전략 대안을 모색할 필요가 있다 고 판단되었다.

지금의 LG화재는 1959년 '범한해상'이라는 브 랜드로 출발하여 1988년에 ‘럭키화재’로, 그리고 1995년에 'LG화재'로 교체되면서 지니게 된 기 업브랜드이다(〈그림 2〉 참조). 1999년 LG그룹 으로부터의 계열 분리로 인하여 2000년 1월부 터는 그래픽 아이콘만 바꾼 상태로 LG화재라 는 브랜드를 사용해 왔었다. "LG" 브랜드가 지 닌 긍정적 이미지를 전이 받기 위해서 일단은 2004년 12월 말까지 5년간은 무상으로 “LG" 브랜드를 계속 사용하는 것으로 LG그룹측과 협의하였다. 1999년에 계열분리를 한 이후 2004 


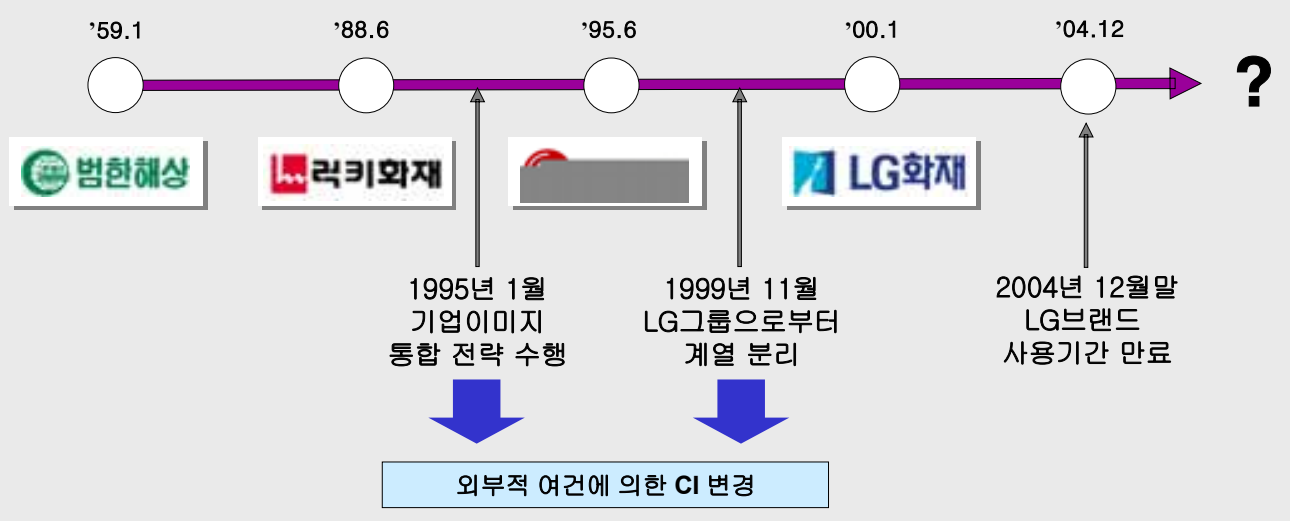

년에 이르기까지, LG그룹의 안정성과 LG브랜 드 프리미엄 이미지를 활용한다는 관점에서 기 업브랜드 변경을 적극적으로 검토하지 않았었 다(〈그림 3 참조). 그 당시 $\mathrm{LG}$ 화재라는 기업 브랜드는 ' $\mathrm{LG}$ '가 주도적 역할을 하며, 하위 브 랜드에 신뢰감을 부여하였고, ‘화재'는 서술자
역할로서 사업분야에 대한 구분을 의미하였다. 2004년까지도 소비자는 LG화재를 LG그룹의 주요 계열사로 인식하고 있어 영업측면에서 많 은 도움을 받고 있다고 조사되었다.

그러나 'LG 그룹'의 자산요소 뿐만 아니라 부 채요소까지 전이되는 면도 있었다. LG카드 사

〈그림 3〉기업브랜드 진단

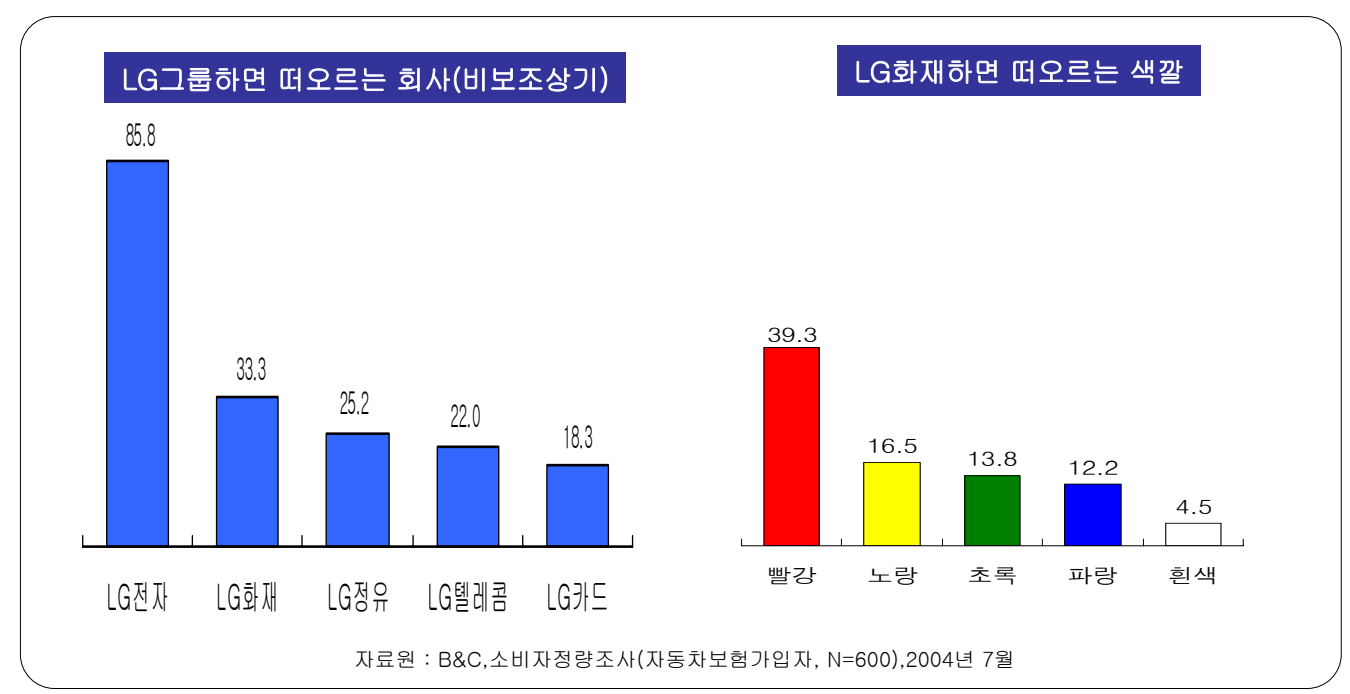

주) 비보조상기도 - 가장 먼저 생각나는 브랜드와 그 다음에 생각나는 브랜드

106 한국마케팅저널 제10권 제3호 2008년 10월 
태 발생을 계기로 대내외적으로 부정적 인식이 대두되었고, $\mathrm{LG}$ 화재에도 영향을 미치게 되어 기업브랜드 변경을 심각하게 고민하기 시작했 다. 전체적으로는 $\mathrm{LG}$ 그룹이 친근하고, 국내 대 기업이며, 재정이 튼튼하다는 자산요소도 있지 만, $\mathrm{LG}$ 금융사태로 인한 재정불안과 같은 부채 요소도 함께 존재하고 있어, $\mathrm{LG}$ 화재에 두 가 지 요소 모두가 영향을 미치는 상태였다. 그리 고 $\mathrm{LG}$ 그룹 이미지가 $\mathrm{LG}$ 화재로 전이되는 부분 때문에 'LG 화재'만의 독립된 브랜드 자산 구 축이 어렵다는 문제점도 있었다. $\mathrm{LG}$ 는 삼성 다음 브랜드로 항상 2 등이라는 이미지 때문에 $\mathrm{LG}$ 화재가 일등보험금융그룹이라는 브랜드위상 과 포지셔닝을 구축하는데 부정적으로 작용하 였다.

\section{2 대소비자 및 사내 커뮤니케이션 진단}

$\mathrm{LG}$ 화재가 지향하고자 하는 브랜드 아이덴티
티 관점에서 소비자들에게 통일되고 유기적인 이미지를 전달하고 있는지에 대한 점검과 관리 가 필요한 시점이 된 것이다. 사회공헌활동, 이 벤트 및 협찬 등 온라인과 오프라인을 통해 브 랜드 자산가치 구축활동에 연계한 적극적 홍보 활동을 시작하였다. 온라인의 경우는 특성상 단발성 이벤트에 그치는 경우가 많아 오프라인 마케팅활동과 연계할 수 있는 활동들을 계획하 였다(〈그림 4〉참조).

한편 기업과 직원, 영업가족 간에 정보를 공 유하도록, 소비자 접점에 있는 영업가족과 관련 부서의 직원들이 기업메시지의 전달자로서 그 기능을 원활히 수행할 수 있는 사내커뮤니케이 션 체계를 갖추고자 하였다. LG화재의 서비스 품질은 경쟁사와 비슷한 수준으로 파악되나 영 업가족과 직원은 경쟁사 대비 낮게 평가하고 있었는데, 그 원인은 기대수준의 차이에 기인한 것으로 파악되었다. 2004년 8월의 조사결과에 의하면 서비스 품질에 대한 만족도는 경쟁사 3

〈그림 4〉대소비자 커뮤니케이션 진단

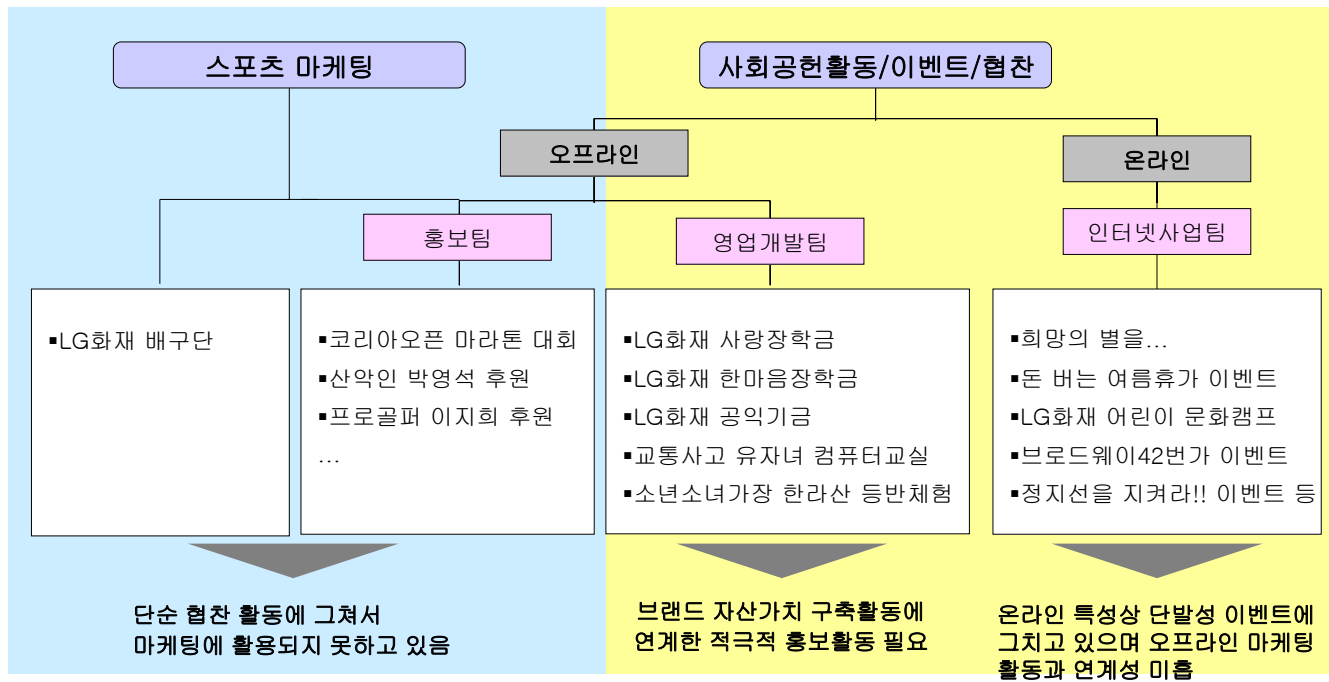


〈그림 5〉사내 커뮤니케이션 진단

\begin{tabular}{|c|c|c|c|c|c|}
\hline & \multicolumn{5}{|c|}{ 실체 } \\
\hline & \multicolumn{5}{|c|}{ <서비스 품질- 긴급출동 서비스> } \\
\hline & \multicolumn{2}{|c|}{ 출동시간 } & \multicolumn{3}{|c|}{ 만족도 } \\
\hline & $\begin{array}{l}30 \text { 분 } \\
\text { 이내 }\end{array}$ & $\begin{array}{l}30 \text { 분 } \\
\text { 이상 }\end{array}$ & 만족 & 보통 & 불만족 \\
\hline LG화재 & 97.8 & 2.2 & 93.2 & 6.0 & 0.8 \\
\hline $\begin{array}{l}\text { 경쟁 } \\
3 \text { 사 }\end{array}$ & 97.7 & 2.3 & 92.3 & 6.2 & 1.5 \\
\hline \multicolumn{6}{|c|}{ <Infra - 보상서비스망 > } \\
\hline & \multicolumn{2}{|c|}{$\begin{array}{l}\text { 보상인원 } \\
\text { (단위:명) }\end{array}$} & \multicolumn{2}{|c|}{$\begin{array}{l}\text { 가맹젖 } \\
\text { (단위:점) }\end{array}$} & $\begin{array}{l}\text { 현출인원 } \\
\text { (단위:명) }\end{array}$ \\
\hline 삼성화재 & \multicolumn{2}{|c|}{1,785} & \multicolumn{2}{|c|}{600} & 144 \\
\hline 현대해상 & \multicolumn{2}{|c|}{1,030} & \multicolumn{2}{|c|}{565} & 41 \\
\hline 동부화재 & \multicolumn{2}{|c|}{1,002} & \multicolumn{2}{|c|}{553} & 53 \\
\hline LG화재 & \multicolumn{2}{|c|}{952} & \multicolumn{2}{|c|}{560} & 103 \\
\hline
\end{tabular}

인식
영업가족
서비스품질이 아직
미흡하다고 생각함
“보상에서만 잘해주면 LG는
앞서갈 수 있어요."
"스피드하게 출동되려면,
우리는 인원을 보충해야
하지 않을까 싶어요"
직익:원
B\&C, 설계사 정성조사, 2004년 7월)
Infra구축이 미흡하다고 생각함.
시스템을 만드는 건 본사 차원에서
고민을 하고 적용을 해야 하는데
그걸 못했다는 거예요."
(죠원:B\&C, 임직원 인터뷰, 2004년 7월)

사의 경우 $92.3 \%$ 가 만족한다고 답변하였고, $\mathrm{LG}$ 화재는 $93.2 \%$ 가 만족한다고 답변하였다. 하 지만 영업가족들은 서비스품질이 아직 미흡하 다고 인식하고 있었다(〈그림 5〉참조).

직원과 영업가족들은 $\mathrm{LG}$ 화재의 이미지를 'LG 그룹'의 한 부분으로 인식하고 업계 1 위의 삼성 에 견주어서 평가하기 때문에 기대수준에서 차 이가 발생하고 있음을 발견했다. 이로써 'LG화 재'의 비전과 기업브랜드에 대한 커뮤니케이션 강화를 통해 서비스품질의 현수준을 인식하고 목표를 공유할 필요성이 제기되었다. 또한 $\mathrm{LG}$ 화재의 서비스 경쟁력 강화가 2003년도 하반기 부터 본격적으로 이루어져 내부직원이 개선된 서비스력을 인식하는 데까지 시차가 발생하고 있다는 점도 또한 지적되었다. 이러한 인식의 시차를 최소화할 수 있는 효과적인 커뮤니케이 션의 도입이 필요할 것으로 판단되었다.

\section{3 브랜드 아이텐티티 전략}

브랜드 아이텐티티 전략을 개발하기 앞서 2004 년 당시 $\mathrm{LG}$ 화재는 자사가 추구할 브랜드 리더 쉽의 유형을〈그림 6 〉과 같이 정의하였다.

삼성화재/동부화재/현대해상 등 경쟁기업의 브 랜드 리더쉽 지향성을 파악하고, 소비자의 특성 과 니즈에 대한 세밀한 분석을 토대로, 일등보 험금융그룹이라는 비전을 달성하는 것이 $\mathrm{LG}$ 화 재의 브랜드 리더십이라고 정의하였다.

$\mathrm{LG}$ 화재가 추구해야 할 브랜드 리더십의 유형 은 “영감을 주는(Inspiring)" 리더라고 제시하 였다(〈그림 7〉 참조). 즉 $\mathrm{LG}$ 화재는 영감을 주 는 리더라는 포지션을 기반으로 일등보험금융 그룹이라는 비젼을 달성하고자 하려는 것이다. 기업의 본원적 능력을 무기로 기능적 역할에 부 응하여 막강한 시장을 점유하고 있는 리더를 “능 력기반의 리더(Capability Oriented Leader)", 소비자의 편익을 가장 중시하는 리더를 “소비 
〈그림 6〉 브랜드 리더십 설정의 토대가 되는 요소들

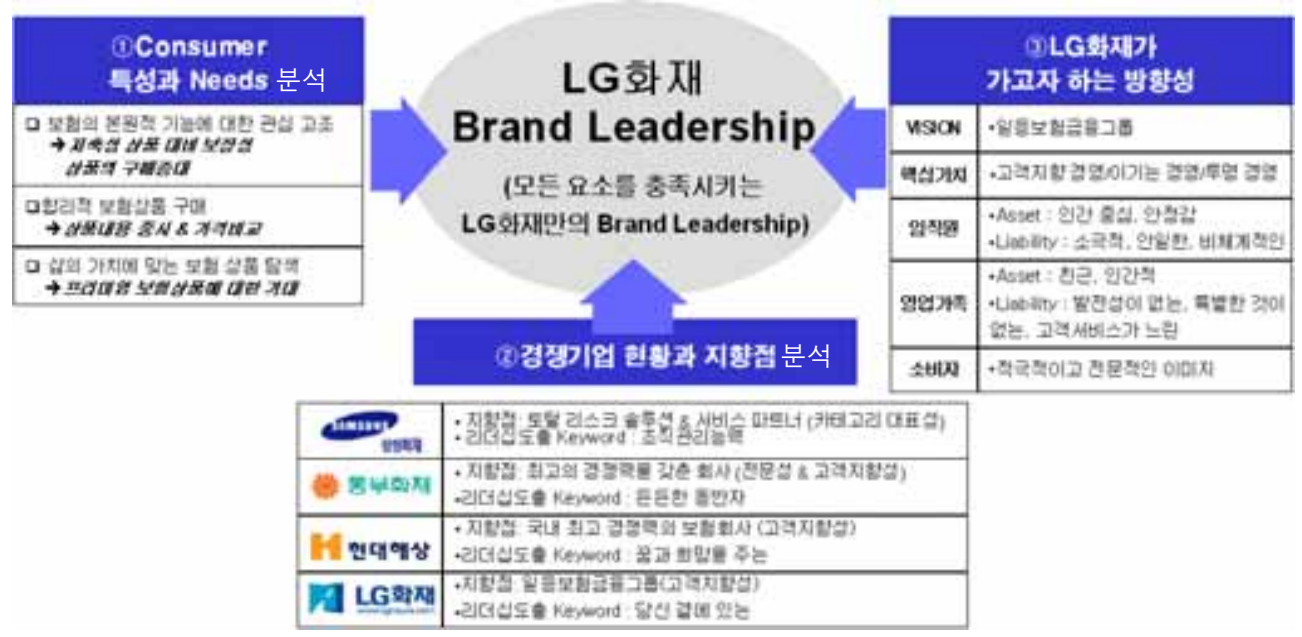

자기반의 리더(Customer Oriented Leader)", 비전을 바탕으로 새로움을 추구하는 창의적인 리더를 "비전기반의 리더(Vision Oriented Leader)" 로 리더의 유형을 나누어 볼 수 있는데, $\mathrm{LG}$ 화 재는 “소비자기반의 리더”와 “비전기반의 리 더”를 겸하고 있는 “영감을 주는(Inspiring) 리
더”가 되어야 한다고 제안하였다. 즉 $\mathrm{LG}$ 화재는 소비자편익과 삶에 대한 희망을 제공하는데 있 어 선도적인 기업브랜드가 되고자 한다. $\mathrm{LG}$ 화 재는 미래의 위험을 대비하는 부정적 요소의 감소라는 소비자편익 측면뿐 만 아니라 삶에 대한 희망을 공유하고 후원하는 긍정적 요소의

〈그림 7〉 브랜드 리더십 유형 설정

- Capability Oriented Leader :

기업의 본원적 능력을 무기로 기능적 역할에 충실함으로써 높은 시장점유율을 갖고 있는 리더

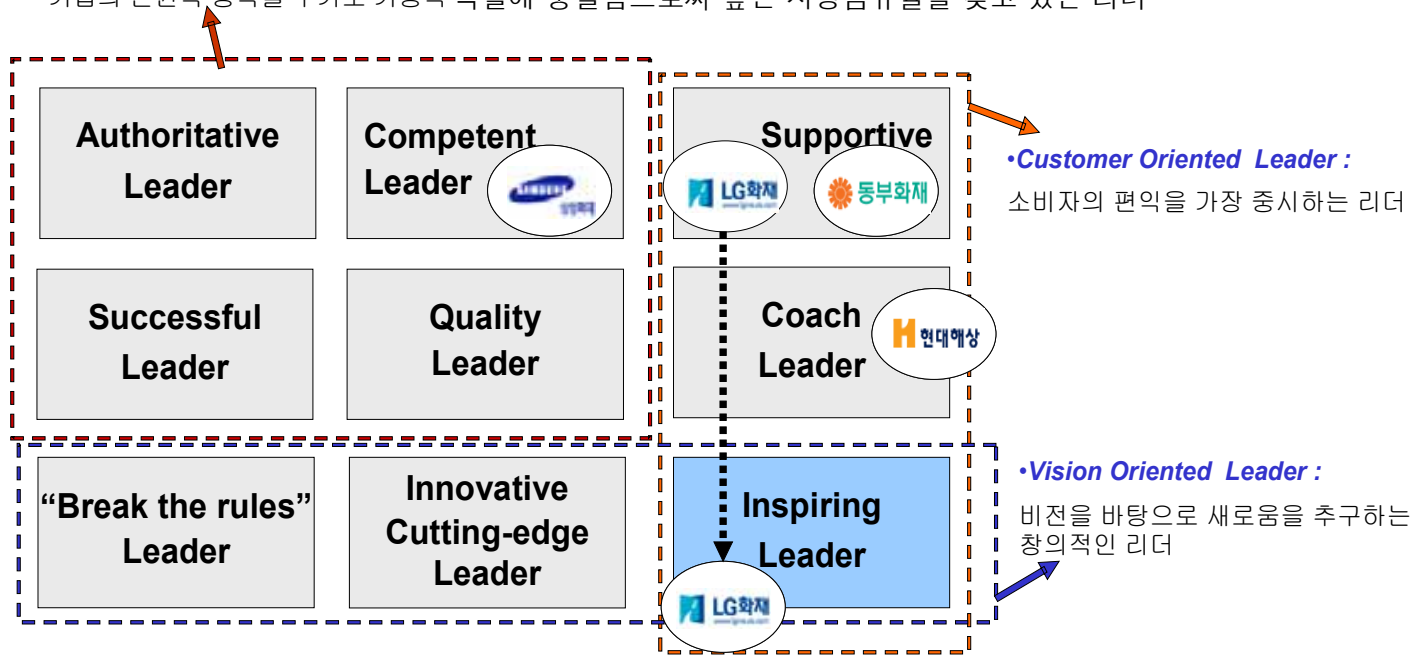


강화라는 비젼적 측면에서 브랜드 리더십을 창 출하고자 하였다.

브랜드 아이덴티티 전략을 개발함에 있어 LG 화재는 브랜드 에센스와 브랜드 아이텐티티를 구분하였다. 브랜드 에센스는 브랜드 리더십을 통해 설정된 목표/가치를 표현하는 것으로써, 브랜드가 무엇을 상징하는지 짧게 압축시켜 브 랜드의 핵심을 파악하게 해 주는 단일개념이 다. 브랜드 아이덴티티는 기업이 브랜드마케팅 을 통해 달성하고자 하는 목표로서, 핵심아이 덴티티와 확장아이덴티티로 구성된다. 내부 직 원에게는 조직의 목표를 전달해야 하고 고객에 게는 우리 브랜드가 어떤 성향이며, 어떤 의미 를 지니고 있는지를 제공하는 것이 바로 브랜 드 아이덴티티의 역할이라 할 수 있다(〈그림 8) 참조).

\section{〈그림 8〉 브랜드 아이덴티티 개요}

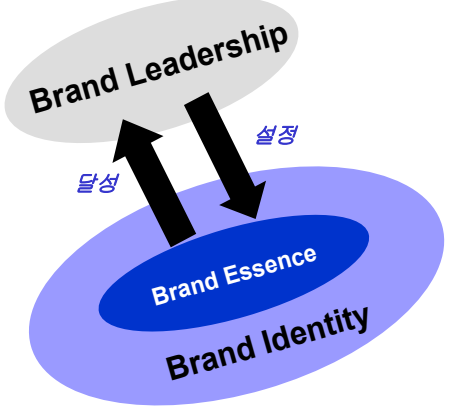

고객의 삶 속에서 고객보다 먼저 니즈를 발견 하고, 이에 대한 해결책을 제시하고, 미래에 대 한 보다 나은 비전을 제시하는 한발 앞선 $\mathrm{LG}$ 화재를 지향하기 위해, "Always Ahead(언제나 한걸음 먼저)”를 브랜드 에센스로 삼았다. 이러 한 브랜드 에센스는 3 가지 하위차원들로 구성
된다. 브랜드 에센스는 [언제나 한걸음 먼저 생 각하고], [언제나 한걸음 먼저 다가가고], 그 리고 [언제나 한걸음 먼저 나아가겠습니다] 로 구체화되는데, 그 중심에는 '언제나 한 걸 음 먼저'라는 내부정신이 자리잡고 있다(<그 림 9> 참조).

LG화재는 'Always Ahead(언제나 한걸음 먼 저)'라는 브랜드 에센스를 바탕으로 'Inspiring brand Leadership'이라는 브랜드 리더십을 실 현하고자 한다. 핵심(Core) 아이덴티티로는 (1) 최고의 상품과 서비스, (2)보험을 중심으로 한 종합금융 인프라, (3) 풍요롭고 가치 있는 삶 을 제시하였고, 확장(Extended) 아이텐티티는 (ㄱ)상품과 서비스, (ㄴ)사회공헌, (ㄷ) $\mathrm{CEO,}$ (ㄹ)LG화재인, (ㅁ)배구단, (ㅂ)인재니움 요소 등을 포함한다. '상품과 서비스'는 한걸음 먼저 고객의 입장에서 생각하고 미래에 대한 자신감 을 갖게 해 주는 근원이며, '사회공헌'은 나눔 경영을 적극적으로 실현하여 믿을 수 있는 기 업을 만드는 활동이다. 'CEO'는 도전정신과 비 전경영을 통해 업계를 선도하는 리더이고, 'LG 화재인'은 고객에게 한걸음 먼저 다가가고 사회 에 봉사할 줄 아는 보험금융 전문가이다. '배구 단은 활력있는 플레이와 세련된 매너를 갖춘 코트의 승부사이고, '인재니움'은 혁신을 선도하 는 창의적인 리더들의 배움터라고 정의하였다.

$\mathrm{LG}$ 화재는 브랜드 아이덴티티를 바탕으로, 고 객의 삶 속에서 고객보다 먼저 니즈를 발견하 고, 고민하고, 해결책을 제시하며, 미래에 대한 보다 나은 비전을 제시함으로써 “삶의 소중함 을 함께 가꿔나가는 동반자”라는 긍정적 브랜 드-고객 관계를 형성하고자 하였다. 긍정적 브 랜드-고객 관계를 구축/강화하기 위해 LG화재 
〈그림 9>브랜드 에센스의 하위차원들

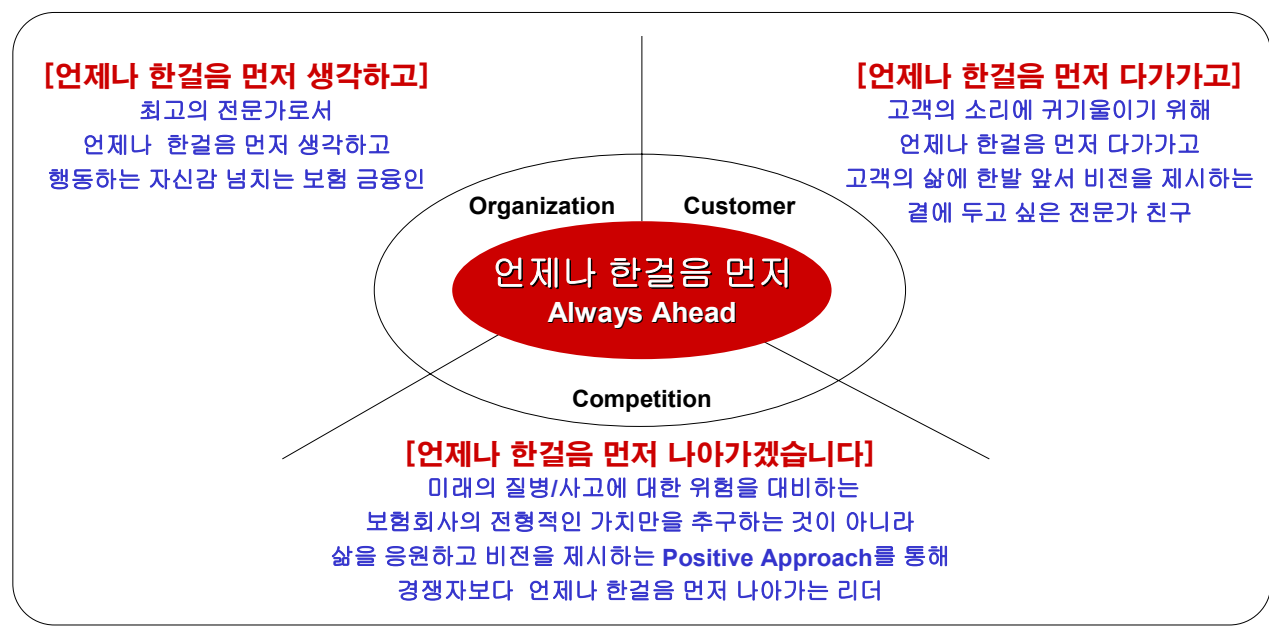

\section{Always Ahead(AA Spirit)}

는 고객에게 3 가지 편익을 전달하고자 하였는 데, (1)고객의 기대를 앞서가는 양질의 상품과 서비스의 전달을 통한 '기능적 편익(Functional Benefit)'의 제공, (2)안정적이고 신뢰할 수 있 는 상품과 서비스를 선택했다는 만족과 자부심의 부여를 통한 '정서적 편익(Emotional Benefit)' 의 제공, (3)앞서 미래를 준비할 줄 아는 유능 한 사람이라는 느낌과 삶을 소중히 여기며 삶 의 자신감과 긍지를 갖고 있는 사람이라는 느낌 의 경험을 통한 '자아표현적 편익(Self-Expressive Benefit)'의 제공이 그것이다.

브랜드 아이덴티티를 체계화하기 위해 정의했 던 브랜드 리더십, 브랜드 에센스, 핵심 아이덴 티티, 확장 아이덴티티, 가치제안, 브랜드-소비 자 관계를 바탕으로 적극적인/세련된/지적인/ 긍정적인/따뜻한 이미지를 브랜드 개성으로 제 시하였다(〈그림 10〉참조).

$\mathrm{LG}$ 화재는 일등보험금융그룹이라는 기업비전
과 Always Ahead(AA Spirit)이라는 브랜드 에센스를 담아 기업브랜드가 궁극적으로 지향 하는 가치를 "Leading Insurance Group"로 정 의하였다. 기업브랜드가 지향하는 가치가 소비 자 언어로 전달되도록 커뮤니케이션 슬로건을 "Lffe is Great/"으로 설정하였다..

\section{4 브랜드 아키텍처의 설계}

LG화재 브랜드 아키텍처 전략을 위해 우선적 으로 그룹관점의 브랜드 아키텍처 정립이 필요 하였다. 2004년 기준으로는 LG화재 산하에 럭 키생명, 럭키손해사정 등과 같이 $\mathrm{LG}$ 화재가 그 룹브랜드로서 일관된 아이덴티티를 정립하는데 한계가 있었다. 이를 일관되게 그룹명을 딴 하 위브랜드 전략을 이용하여 통일성있는 아이덴티 티를 정립하고자 하였다. 그룹명은 태생적 가치 인 Lucky Insurance Group, 지향가치인 Leading 


\section{〈그림 10〉브랜드 아이덴티티 시스템}

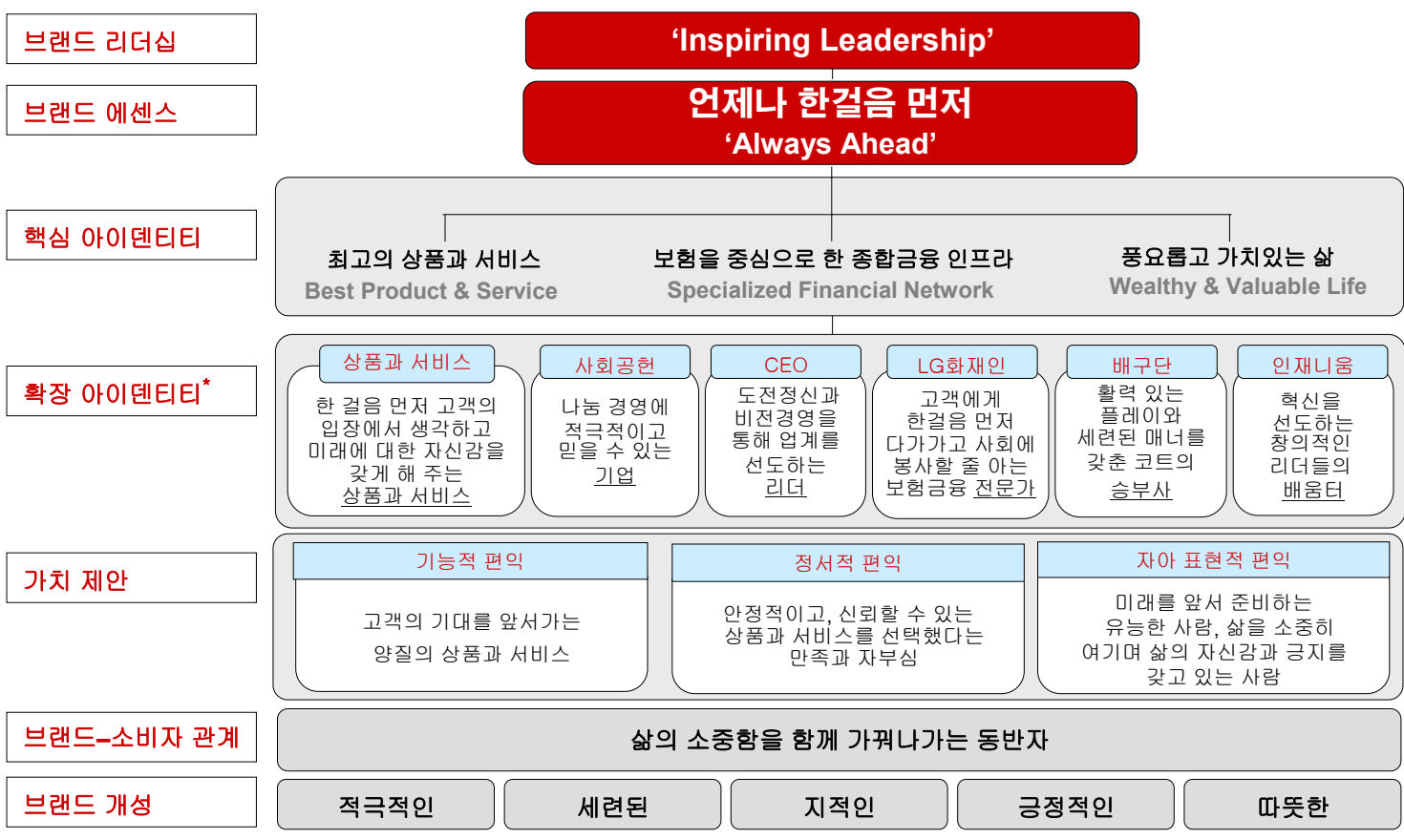

${ }^{*}$ Extended-Identity(확장아이덴티티)는 브랜드를 표출하는 소비자 접점의 모든 요소가 될 수 있으며, 각 요소에 브랜드 에센스를 적용한 것을 의미함.

Insurance Group, 그리고 전달가치인 Life is Great의 약자에 해당하는 'L,'I','G'를 따서 LIG 화재라는 새로운 기업브랜드를 만들어냈다. 이 리하여 $\mathrm{LIG}$ 손해보험 산하에〈그림 11 〉과 같이 $\mathrm{LIG}$ 생명, $\mathrm{LIG}$ 손해사정 등과 같이 일관된 브랜 드 아키텍처를 정립하였다.

\section{5 브랜드 커뮤니케이션 전략}

커뮤니케이션 전략의 출발은 소비자에게 전달 하고자 하는 목표 이미지 영역을 설정하는 것 이다. LG화재가 꼽고 있는 가치는 내부공유가 치, 지향가치, 그리고 전달가치로 나누어 볼 수 있다. 내부공유가치는 Always Ahead(AA Spirit), 지향가치는 'Leading Insurance Group' 그리고
전달가치는 “Life is Great!”으로서, 소비자 인 식속에 LG화재는 삶의 소중함을 함께 가꿔 나 가는 동반자라는 이미지를 심고자 하였다.

브랜드 커뮤니케이션을 위한 이미지 MIX전 략을 위해 $\mathrm{LG}$ 화재가 지향할 주된 이미지를 추 출해야 한다. 지향가치인 'Leading Insurance Group'은 적극성/전문성/ 투명성의 이미지를 지 향하고, 전달가치인 "Life is Great!"은 안정성/ 고급성/친근성의 이미지를 지향한다. “적극성” 의 이미지는 경쟁을 주도할 이미지로, 다른 이 미지에 파급효과가 높은 이미지라 판단하였으 며, “고급성”의 이미지는 경쟁사와 차별화 되 고, 새로운 이미지 개발에 효과적인 이미지라고 판단하여, “적극성”과 “고급성”을 주된 지향이 미지로 삼았다. 이리하여 광고 등 커뮤니케이션 
현재

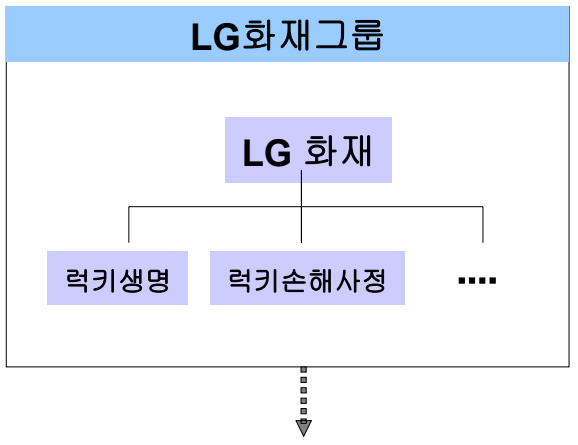

- 그룹브랜드로서 일관된 아이덴티티 정립의 한계
향후

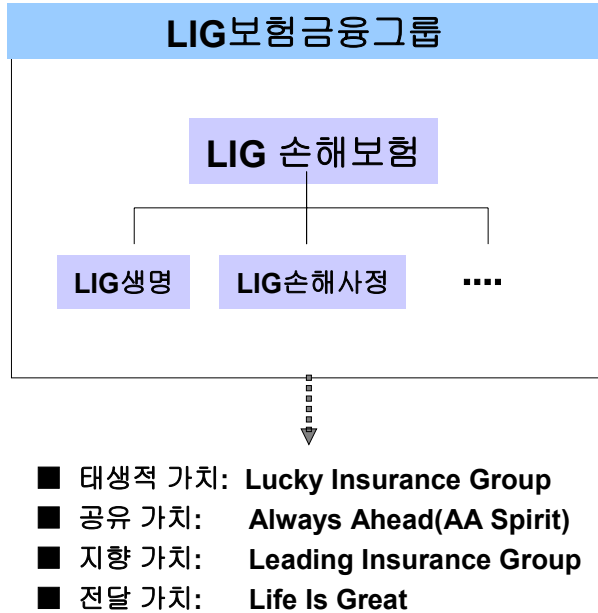

다 강력한 연상이 창출되도록 만들어 브랜드 사용에 따른 사용자 만족의 정서적 가치를 향 상시키고자 하였다. 3 단계에서는 고객과의 관계 를 강화하여 브랜드 로열티를 향상시킴으로써 브랜드 철학과 비전을 공유하여 자아표현적 가 치를 높이고자 하였다.

브랜드 자산구축을 위해 통합적인 커뮤니케이 션을 적용하기 위해 광고/홍보/이벤트마케팅 및 후원/프로모션/인적판매에 따른 커뮤니케이 션 전략을 개발하였다. 광고는 $\mathrm{TV}$, 라디오, 신 문, 잡지, 인터넷을 통한 대중매체와 더불어, 우 편/전화 등을 활용한 직접반응광고, 옥외 공간 광고, 구매시점 광고를 통한 비대중매체를 활용 하여 브랜드 인지도를 제고하고 브랜드 이미지 를 구축하도록 적용하고자 하였다. 판매촉진은 쿠폰, 프리미엄, 보너스, 가격인하를 통해 보다 많은 소비자들이 체험할 수 있는 기회를 제공 하고자 하였다. 
〈그림 12〉 브랜드 커뮤니케이션을 통한 브랜드자산 구축 방향

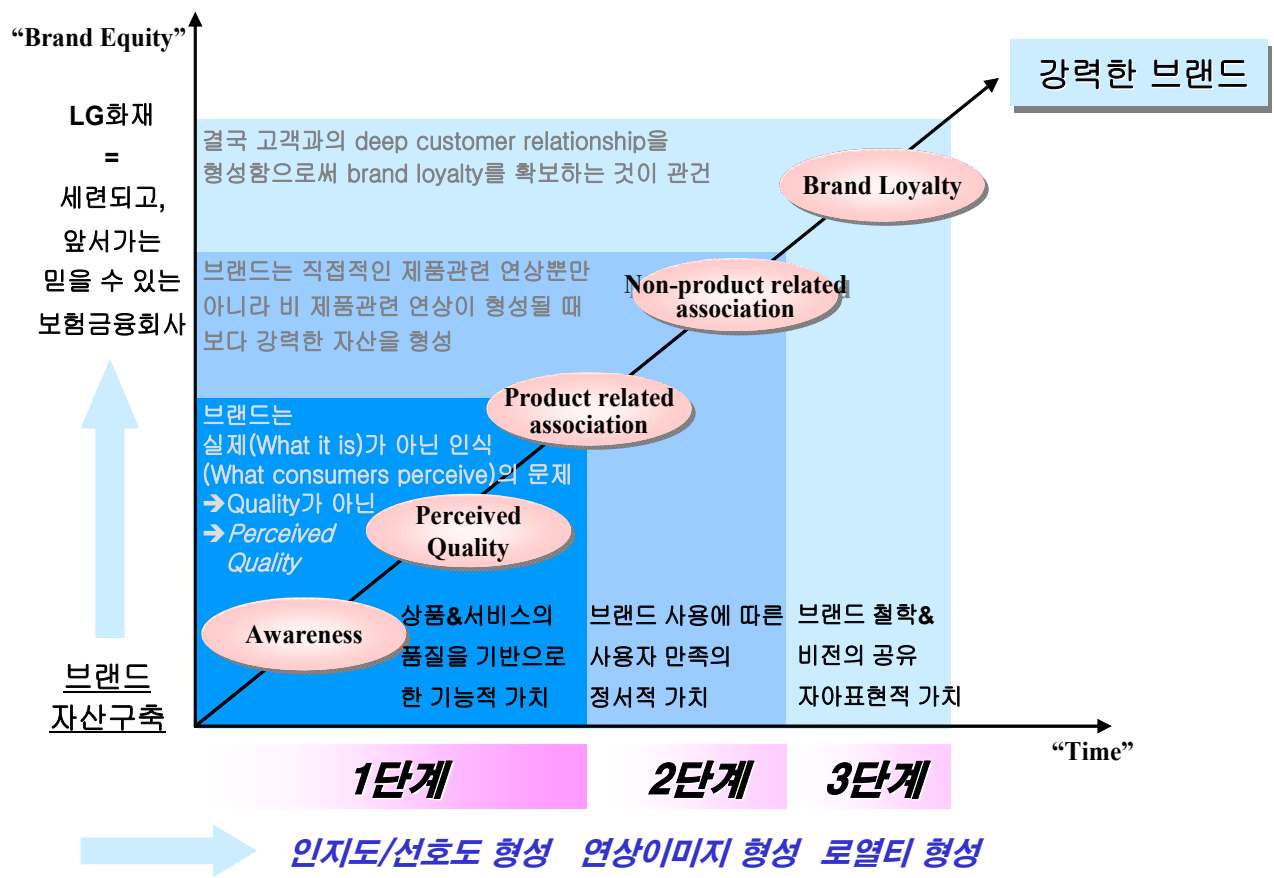

대중매체는 광고를 통해 브랜드 인지도 제고 하고 'Life is Great!' 이미지 구축하여 기업브 랜드 교체 준비단계에서 적극적으로 활용하기 로 하였다. 비대중매체는 'Leading Insurance Group' 이미지를 구축하고, 또 한편에서는 사회 공헌/스포츠 문화활동을 통해 'Life is Great!' 이미지 체험을 제공하도록 하였다. '삶의 소중 함을 함께 가꿔 나가는 LG화재'의 이미지를 만 들 수 있도록 모든 대외 커뮤니케이션은 〈표 2)와 같이 일관되게 진행시켜 나갔다.

커뮤니케이션 활동 중 사회공헌활동에 대해 더욱 세밀한 계획을 세웠다. 삶을 소중히 하는 믿을 수 있는 기업으로 포지셔닝하기에 사회공 헌활동이 효과적이라고 판단하였다. 소외되고 상처 받은 어린이를 위한 활동에 집중함으로써, 기존 이미지 중 친근한 이미지를 강화하고 새
로 보강할 이미지인 앞서가는 적극적인 이미지 를 구축하는데 도움이 된다고 판단했기 때문이 다. 이를 위해 사회공헌활동의 대상을 구체적으 로 선정하고 사회공헌활동 방향을 설정하였다. 접근성과 활동효율성이 높은 대상에 대해서는 복지시설 또는 후원단체와 연계하여 지원하였 고, 접근성과 활동효율성이 낮으며 개별적인 보 살핌이 필요한 대상에게는 직원들로 이루어진 팀별로 지체장애아와 결연을 맺는 형태를 통해 보다 개인화된 보살핌을 제공하도록 하였다.

\section{6 기업브랜드 교체 전략}

LG화재는 브랜드자산 강화를 위하여 금융그 룹화를 통한 기업브랜드 신뢰도 제고와 하위브 랜드를 통한 기업브랜드 활성화 전략이 동시에 
〈표 2〉 브랜드 자산구축을 위한 커뮤니케이션 전개 가이드라인

\section{모든 대외 커뮤니케이션은 '삶의 소중함을 함께 가꿔 나가는 LG화재'의 이미지를 만들어갑니다.}

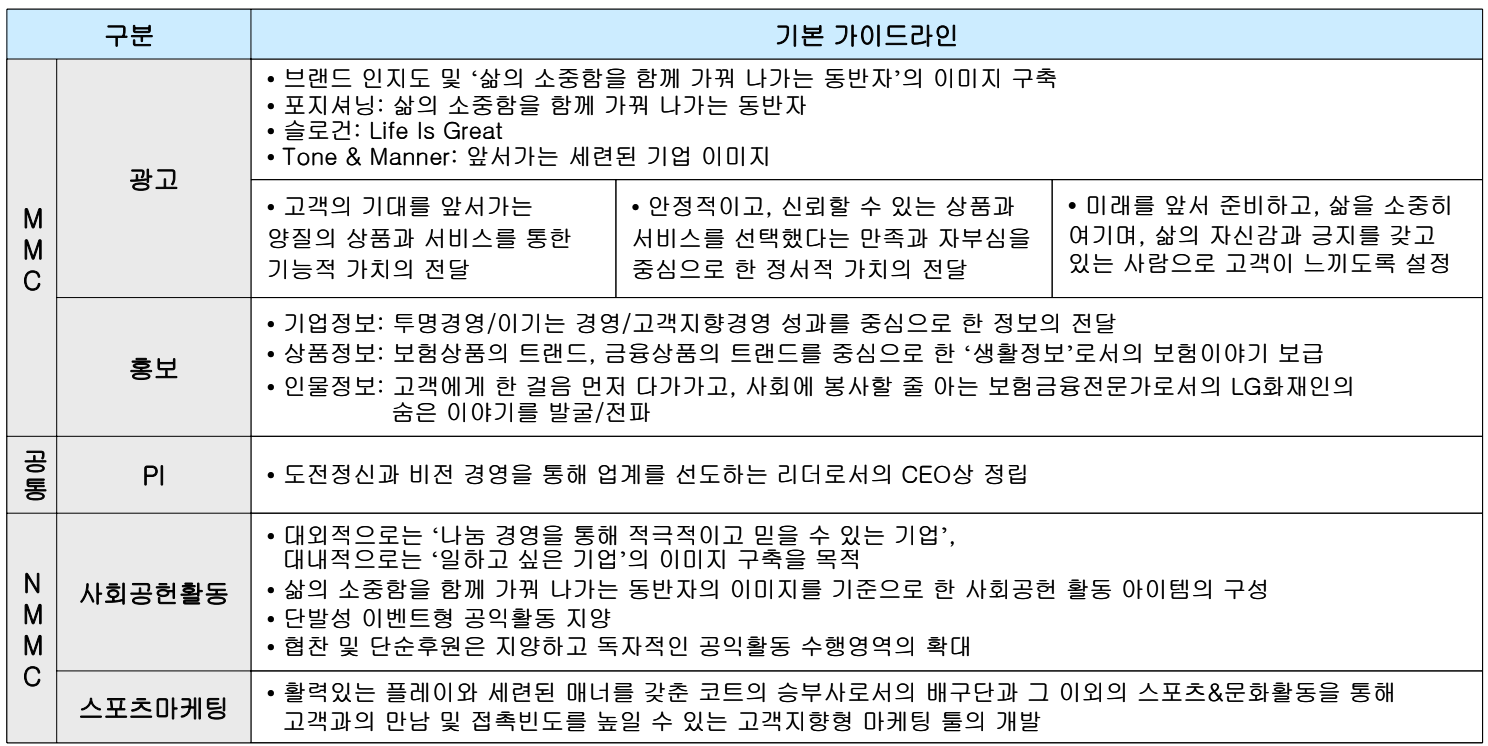

NMMC 중심의 세부 프로그램 개발

유기적으로 이루어져야 했다. 브랜드 교체를 위 한 준비기/진입기/안착기를 통해 LG화재의 브 랜드가치를 감퇴시키고 LIG손해보험의 브랜드 가치를 강화시켜 기업브랜드가 성공적으로 교 체되도록 유도하는 것이다(〈그림 13〉 참조).

$\mathrm{LG}$ 화재의 새로운 브랜드 아이덴티티인 “AA Spirit”과 LG화재가 지닌 정통성과 지속성을 이 어받은 LIG라는 기업브랜드의 적용범위를 LIG 보험금융그룹산하에 LIG손해보험/LIG생명/LIG 손해사정으로 결정하였다. 이때의 LIG의 의미 와 가치는 태생적 가치, 지향가치, 전달가치, 구 축이미지로 나누어 볼 수 있다. 태생적 가치는 'LG화재의 정통성과 지속성: Lucky Insurance Group'에 해당하고, 지향가치는 '일등보험금융 그룹-Always Ahead(AA Spirit): Leading
Insurance Group'에 해당하고, 전달가치는 'Life is Great!'이고, 구축이미지는 '삶의 소중함을 함께 가꿔나가는 동반자라고 볼 수 있다.

이러한 의미의 LIG를 표현할 수 있는 디자인 을 개발하기 위해 먼저 “영감을 주는 리더십 (Inspiring Leadership)" 이라는 브랜드 리더십을 바탕으로 "언제나 한걸음 먼저(Always Ahead)" 라는 브랜드 에센스를 표현할 수 있는 브랜드 개성을 찾고자 하였다. “적극적인” 이라는 개성 은 진취적인/역동적인/혁신적인/최고의/첨단의 /대표의 느낌을 지니고 있고, “세련된”이라는 개성은 가치있는/소중한/미래의/젊은/고급스러 운 느낌을 지니고 있으며, “믿을 수 있는”이라 는 개성은 신뢰/성실한/대표의/단단한/규모감/ 안정감/진실한/깨끗한 느낌으로 표현된다. 그리 
〈그림 13〉 브랜드 자산 강화 전략

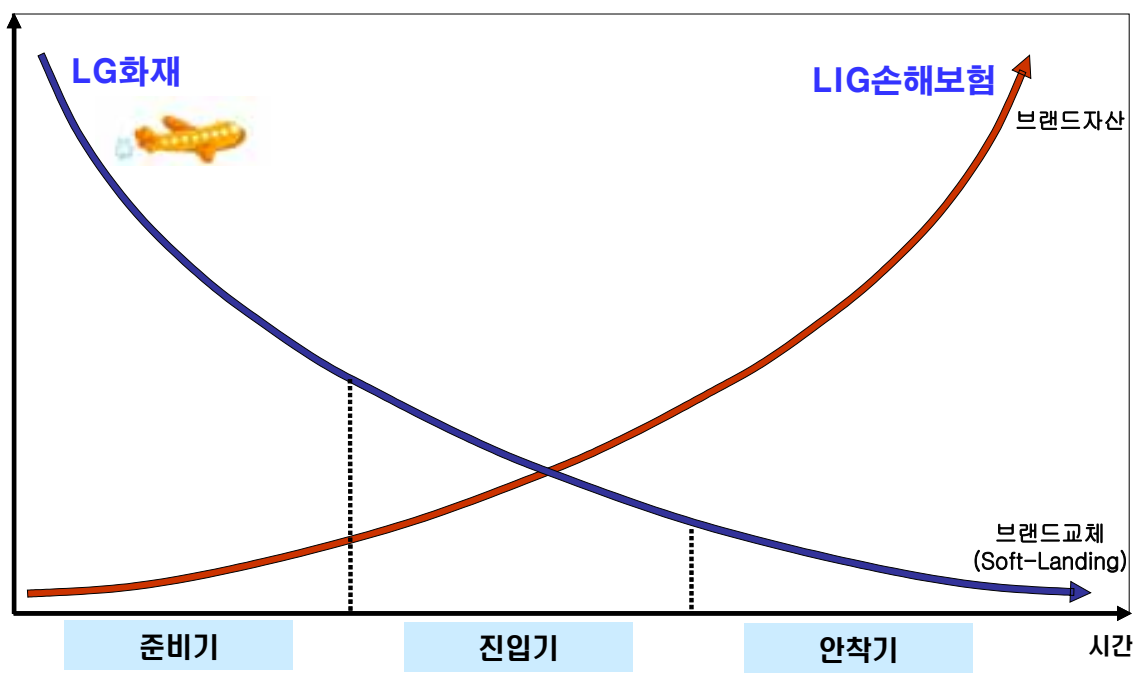

고 “따뜻한”이라는 개성은 밝은/희망/미래의/ 함께/정성/친구/사랑/행복 느낌으로, “지적인” 개성은 친구/지식/전문성/두뇌 느낌으로, "긍정 적인" 개성은 가꾸는/응원/행운/꿈/대비하는/ 만족/희망/밝은 느낌으로 표현될 수 있다.

이러한 개성들을 지닌 $\mathrm{LIG}$ 를 표현할 수 있는 디자인 개발을 위해 기존 기업마크들에 대한 분석이 진행되었다. 심볼마크를 사용한 경우는 의미지향적이고 안정감을 부여하며 정형화된 느 낌을 준다. 반면, 심볼마크와 함께 워드마크를 함께 사용한 경우는 커뮤니케이션을 지향하고 긴장감과 함께 자유스러운 개성을 강조하는 경 향이 있다(〈그림 $14 〉$ 참조).

최근의 $\mathrm{CI}$ 트랜드를 반영하고 보다 시선을 주목시킬 수 있고 기억을 강하게 남길 수 있는 $\mathrm{CI}$ 개발을 위해 2005년 하반기에 다양한 스케치 작업을 돌입하였다. 이 작업은 많은 임직원들의 참여속에 진행이 되었다(〈그림 15〉 참조). 이러 한 노력 끝에 최종후보를 2 가지로 압축한 후
(〈그림 16〉참조), 국민대 시각디자인학과 학생 들과 홍익대 산업미술대학원 광고 디자인전공 학생들에게 선호도 조사를 시행하여, 최종적으 로 $\mathrm{CI}$ 디자인을 선택하였다.

새로운 $\mathrm{CI}$ 는 고객, 주주, 임직원의 행복, 희망, 비전 등을 상징화함으로써 꿈과 무한한 가능성 을 실현하는 $\mathrm{LIG}$ 를 나타내는 것이다. 새로운 $\mathrm{CI}$ 디자인은 기업브랜드인 $\mathrm{LIG}$ 를 나타내는 로 고타입과 LIG의 이미지를 표현하는 그래픽 아 이콘으로 구성되어 있다. 그래픽 아이콘은 고객 의 소중한 꿈과 희망을 지켜주고 실현시켜주는 희망구름을 형상화한 것이다. 희망구름은 'Life Is Great!'라는 LIG의 전달가치를 구현한 것으 로 희망에 가득 찬 고객의 밝은 미래를 상징적 으로 표현하고 있다. 세 개의 원으로 연결된 운 동감 있는 조형은 변화와 혁신을 두려워하지 않는 선도적이고 적극적인 기업의 이미지를 나 타내고 있으며, 유기적인 형태로 고객, 주주, 임 직원 꿈과 희망을 실현시킬 수 있는 무한한 가 


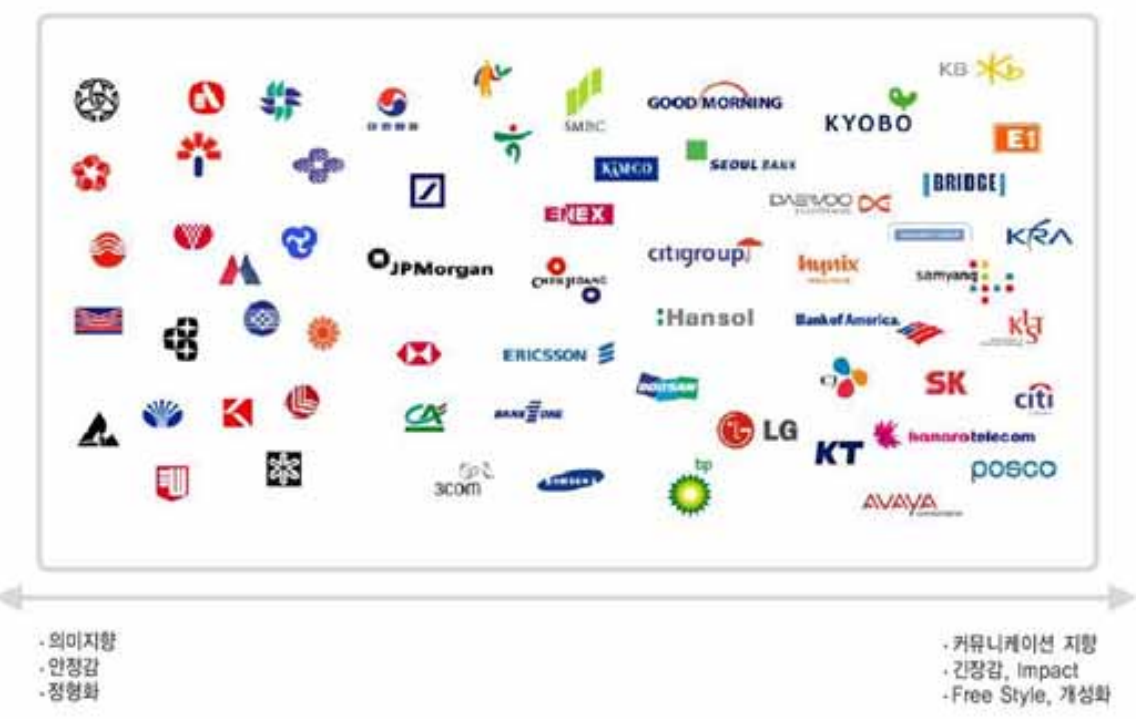

〈그림 15〉 Cl개발을 위한 임직원들의 참여

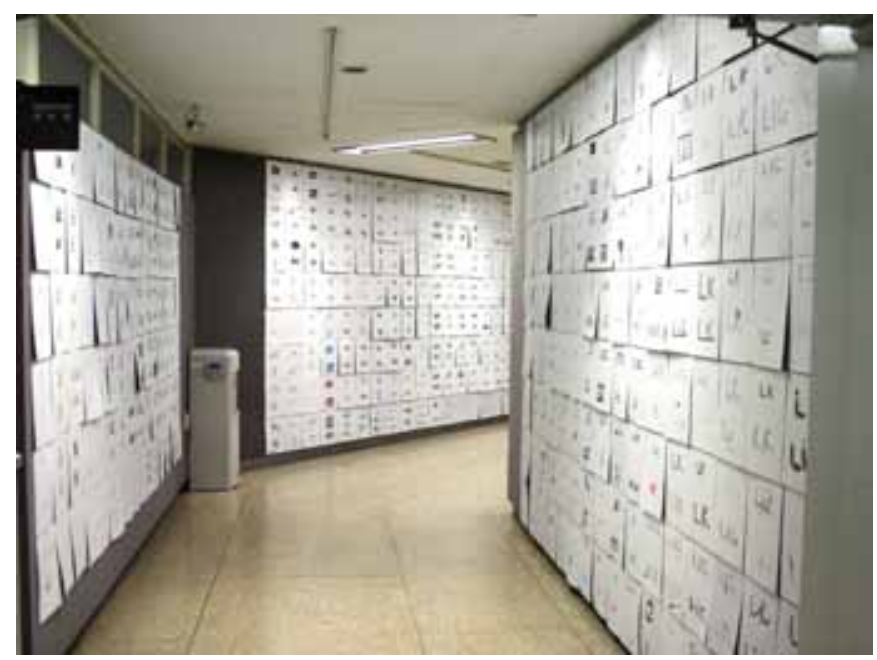

능성과 미래를 표현한 것이다. 희망구름의 각 색깔은 각각 의미를 지니고 있다. 오렌지는 고 객의 색깔로서, 고객의 행복, 즐거움, 따듯함을 의미하고, 파란색은 주주의 색깔로서, 주주의
신뢰, 자신감, 규모감을 의미하며, 녹색은 임직 원의 색깔로서, 임직원의 희망과 생동감을 의미 한다. 
〈그림 16〉 최종 후보들의 연상이미지
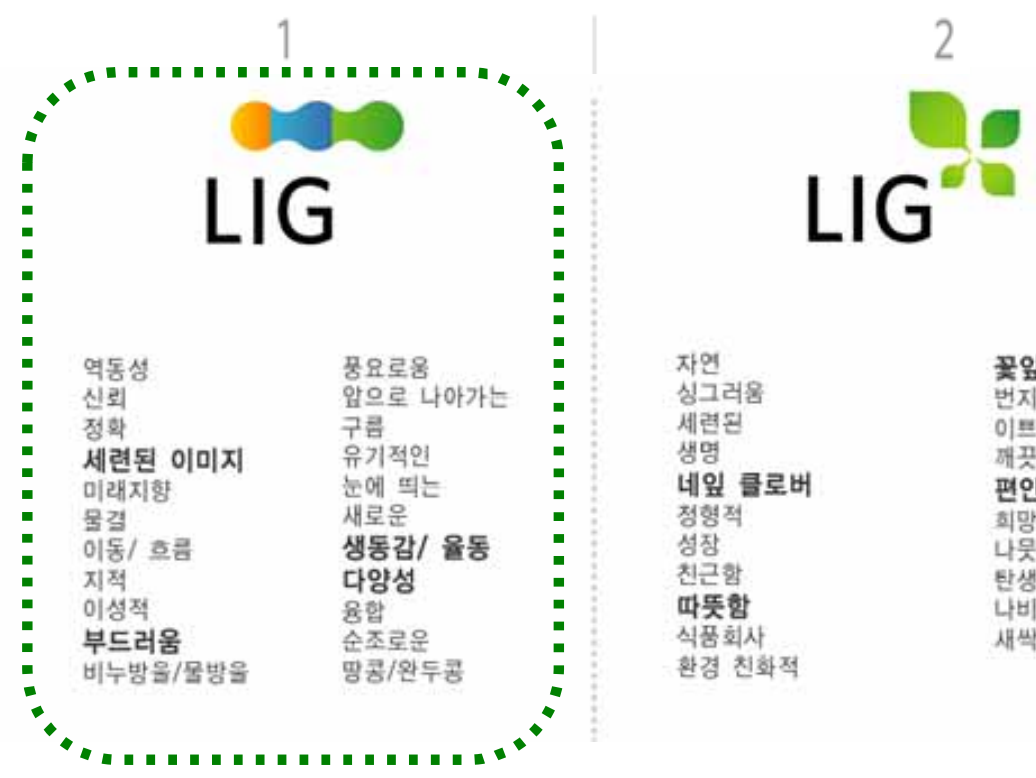

자연

싱그러윰

세련된

생명

네잎 를로버

정형적

성장

친근함

따뜻함

식품회사

환경 친화적
꽃잎

번지는 느낑

이르다

패꼿핸

편안한

획망적

나뭇잎

탄생

나비

새싹

〈그림 17〉 새로운 $\mathrm{Cl}$ 디자인의 활용

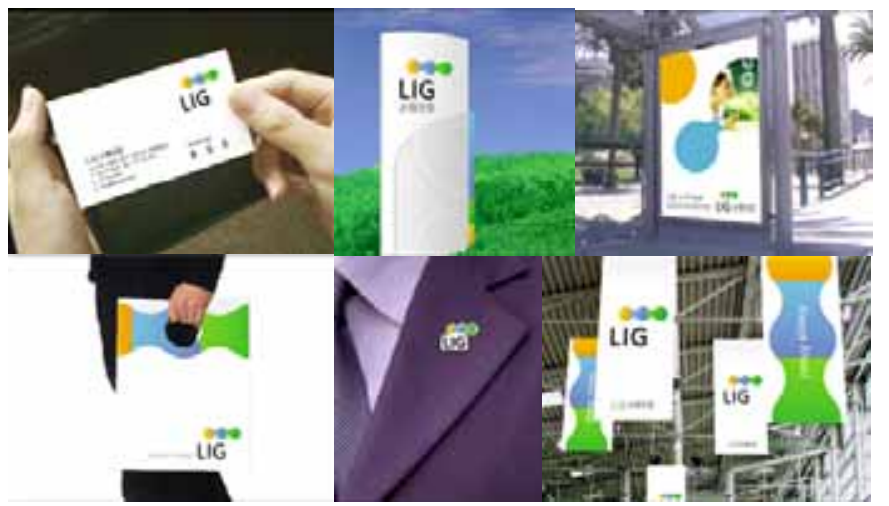

III. 결 론

3.1 새로운 기업브랜드 런칭에 대한 평가

새로운 기업브랜드 런칭을 위해 2006년 3월부 터 TV, 일간지, 이벤트 등을 통해 본격적인 마
케팅활동을 전개하였다. 이들 마케팅활동을 전 개되는 동안, LIG손해보험의 마케팅 및 커뮤니 케이션 전략에 필요한 기초 자료를 수집하기 위해 브랜드 및 광고 인지도 평가와 LIG손해보 험 기업브랜드 변경광고에 대한 소비자 반응을 알아보기로 하였다. 2006년 5월에 20 40대 남 녀 총 360 명을 대상으로 온라인 서베이를 실시 
하였다. 2006년 1월에 시행했던 LG화재에 대한 인지도 평가와 비교했을 때, 최초상기도는 $15.6 \%$ 에서 $12.8 \%$ 로, 비보조 상기도는 $54.0 \%$ 에서 $31.2 \%$ 로, 보조인지도는 $99.2 \%$ 에서 $89.2 \%$ 로 조금씩 하락하였다. 하지만 "LIG손해보험은 LG화재의 새이름이다”라고 옳게 인지하고 있는 경우가 $88.9 \%$ 로 새로운 기업브랜드에 대한 홍보활동이 대체적으로 성공적이라고 판단되었다(〈그림 18〉 참조). 주목할 만한 부분은 $\mathrm{LIG}$ 손해보험 보조 인지도 및 기업브랜드 변경 인지율은 특히 30대 에서 높게 나타난다는 것이다(〈그림 19〉 참조).

$\mathrm{LIG}$ 손해보험을 인지하게 된 경로로는 TV광 고가 $88.1 \%$ 로 가장 많이 차지했고, 인터넷 (38.9\%), TV방송보도 및 뉴스(21.1\%), 신문광 고 $(20.0 \%)$, 신문기사 및 뉴스 $(17.9 \%)$ 순으로 나타났다.
그리고 조사대상 중 $81.1 \%$ 가 "LG화재의 새 이름, $\mathrm{LIG}$ 손해보험”이라는 메시지의 광고를 본 적이 있다고 응답하여, 광고가 새로운 $\mathrm{CI}$ 를 홍 보하는데 효과적인 커뮤니케이션 수단으로 사 용되었음을 알 수 있었다. 여성과 30 대 초반이 메시지 보조만으로도 광고를 상대적으로 더 많 이 기억하고 있었고, LIG손해보험 런칭 광고편 을 보고난 후 $88.6 \%$ 가 광고를 이전에 본 적이 있다고 했으며 연령이 낮을수록 인지율이 높게 나타났다(〈그림 20〉참조).

런칭편 광고를 보고 난 후 기억에 남는 요소 로 배경음악과 가사를 꼽는 사람이 전체 응답 자의 $32.5 \%$ 로 가장 많았고, 아이와 갓난 아기, 김명민 등 등장인물과 가족 전체의 행복한 모 습을 대부분 기억하고 있었다. 그리고 광고 속 성별 평가결과를 살펴보면, 기업브랜드 변경 인

\section{〈그림 18〉 캠페인의 효과}

[ LG화재 인지도 평가 ]

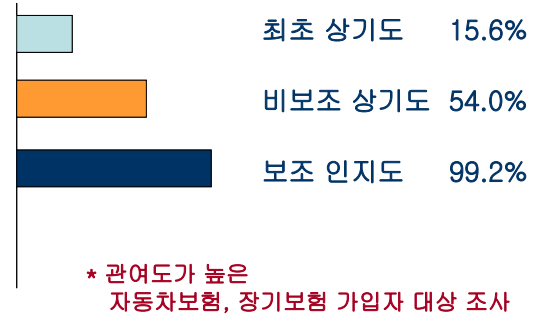

[자료원 : LG화재 내부 LBEI 조사. 개별면접. 2006.1.25]
[ LIG(손해보험) 인지도 평가 ]

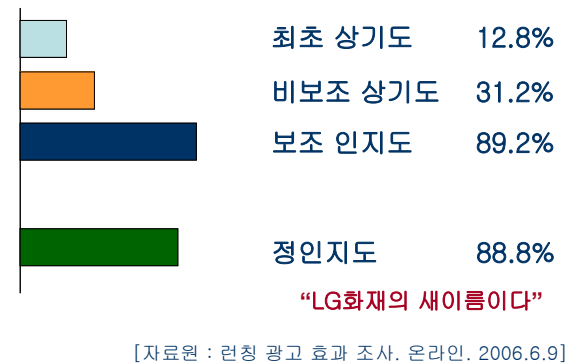

〈그림 19〉LIG손해보험 인지도

\begin{tabular}{|c|c|c|c|c|c|c|}
\hline & \multicolumn{2}{|c|}{ 성 별 } & \multicolumn{4}{|c|}{ 연 령 별 } \\
\hline & 남 & 여 & $20 \sim 29$ & $30 \sim 34$ & $35 \sim 39$ & $40 \sim 49$ \\
\hline 인지 & 90.7 & 86.8 & 90.0 & 93.3 & 86.7 & 86.7 \\
\hline 비인지 & 9.3 & 13.2 & 10.0 & 6.7 & 13.3 & 13.3 \\
\hline
\end{tabular}

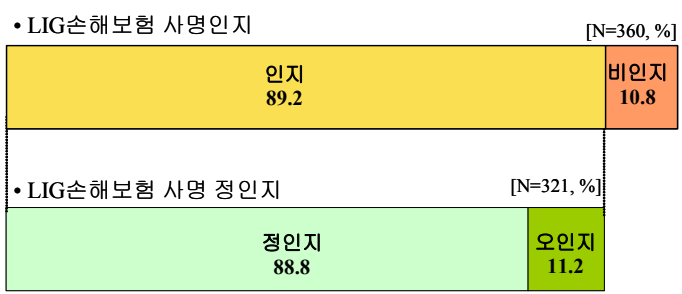

LIG손해보험의 새로운 기업브랜드 전략을 통한 기업이미지 재정립 119 
〈그림 20〉 LIG손해보험 광고 보조인지도

<LIG손해보험 광고 보조인지도 - Main Copy보조>

\begin{tabular}{|c|c|c|c|c|c|c|}
\hline & \multicolumn{5}{|c|}{$\begin{array}{l}\text { 인지 } \\
81.1\end{array}$} & $\begin{array}{c}\text { 비인지 } \\
18.9\end{array}$ \\
\hline & \multicolumn{2}{|c|}{ 성 별 } & \multicolumn{4}{|c|}{ 연 령 별 } \\
\hline & 남 & 여 & $20 \sim 29$ & 30 34 & $35 \sim 39$ & $40 \sim 49$ \\
\hline \multirow{2}{*}{$\begin{array}{r}\text { 인지 } \\
\text { 비인지 }\end{array}$} & 79.2 & 84.0 & 76.7 & 86.7 & 82.2 & 78.9 \\
\hline & 20.8 & 16.0 & 23.3 & 13.3 & 17.8 & 21.1 \\
\hline
\end{tabular}

지, 광고 주목도, 기억 용이성 및 호감도에 있 어서 5점 척도 기준으로 평균 3.50 이상으로 긍 정적인 반응을 보였다(〈그림 21〉 참조). $\mathrm{LIG}$ 손 해보험 광고인지자가 전반적으로 모든 속성 평 가에 대해 긍정적인 응답을 하고 있어, 광고가 $\mathrm{LIG}$ 손해보험의 브랜드 이미지 제고에 긍정적으 로 기여한 것으로 평가되었다.

$\mathrm{LIG}$ 손해보험 광고에 대한 선호도 조사 결과 에서는 전체 응답자의 $90.3 \%$ 가 $\mathrm{LIG}$ 손해보험 광고에 대해 보통 이상의 평가를 하였고, 선호 이유로는 친숙한 노래(32.3\%)>친근함(23.2\%)>
<LIG손해보험 광고 보조인지도 - 동영상보조>

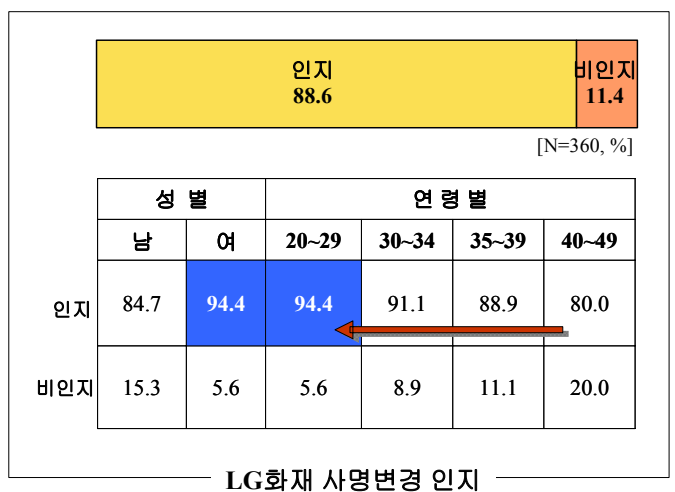

가족의 행복 $(18.7 \%)>$ 모델에 대한 호감 $(12.1 \%)$ 순으로 나타났다. $\mathrm{LIG}$ 손해보험 광고에 비호감 을 나타낸 사람은 $9.7 \%$ 로, 비호감 이유로는 광고 가 단순, 평범하다는 응답이 일부 나타났다(〈그 림 22> 참조). $90 \%$ 가 넘는 응답자가 $\mathrm{LIG}$ 손해 보험 광고에 대해 긍정적인 평가를 하고 것은 고무적인 결과로 평가되었다.

\section{2 기업이미지를 위한 향후 계획}

LIG손해보험은 경영철학인 '고객과 함께 성

〈그림 21〉 LIG손해보험 광고 속성별 평가 - 전체값 VS 광고 인지자

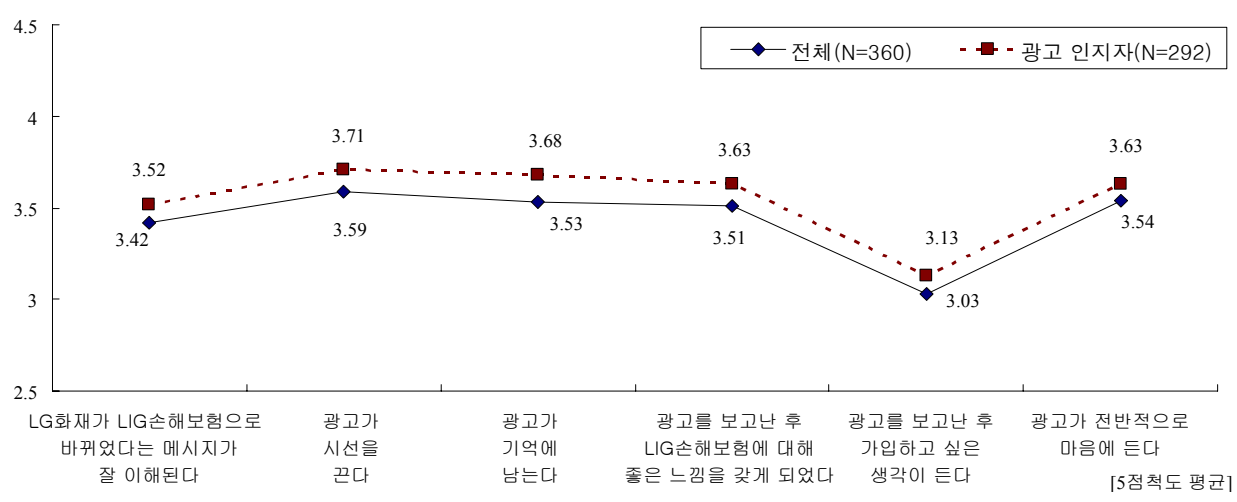

120 한국마케팅저널 제10권 제3호 2008년 10월 
〈그림 22〉 LIG 손해보험 광고 선호도

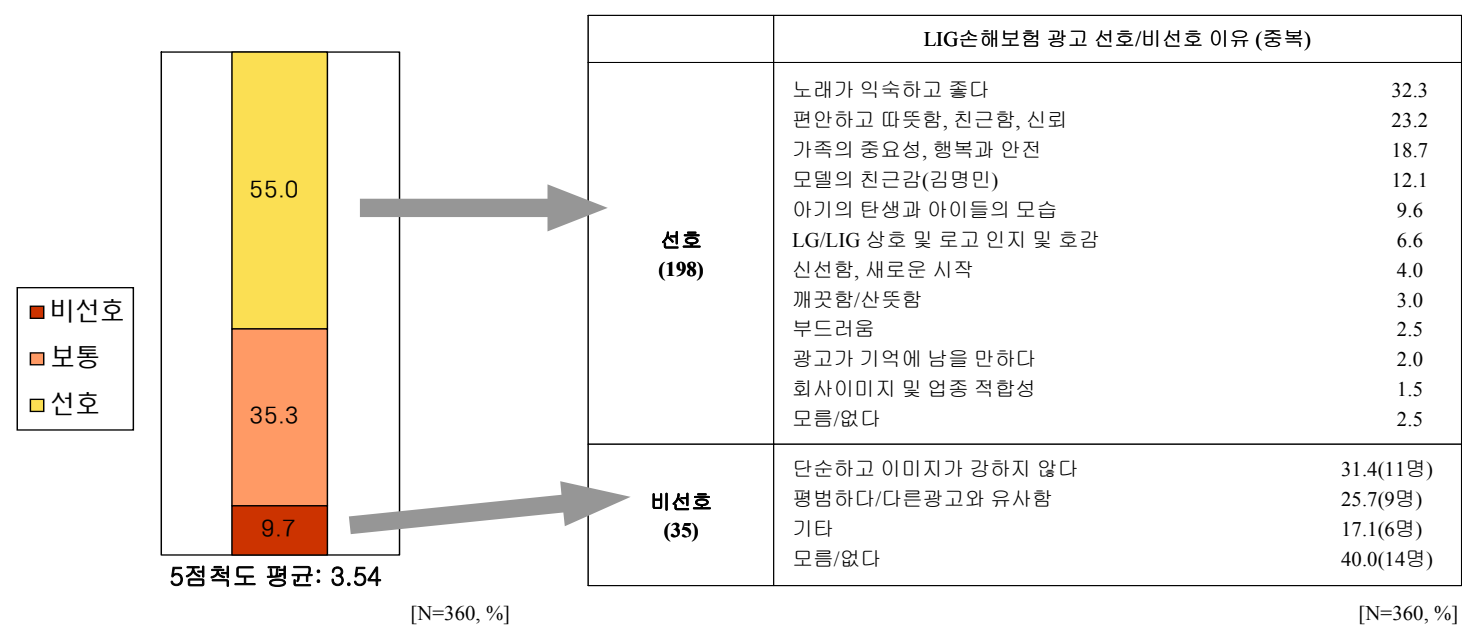

장하며 삶의 소중함을 가꿔나간다'를 실천하기 위해 높은 경영성과에 의한 경제적 책임의 이 행에서 한걸음 더 나아가 사회공헌활동을 통한 비경제적 책임의 실현을 위해 전사적 노력을 기울인다. $\mathrm{LIG}$ 손해보험은 적극적인 사회공헌활 동을 통해 기업의 사회적 책임을 실천함으로써 다양한 이해관계자집단의 마음속에 “고객과 사 회에 희망을 주는 기업”이라는 이미지를 구축
하는 것을 장기적인 기업목표로 삼고 있다(<그 림 23> 참조).

$\mathrm{LIG}$ 손해보험은 사회공헌활동에 기반한 장기 적 기업이미지를 구축하기 위해 〈그림 24〉와 같 이 사회공헌활동을 크게 공익기금사업, 자원봉 사활동, 메세나활동 등으로 구분하여 진행하고 있다.

공익기금사업은 다양한 원천으로부터 창출된

〈그림 23〉 사회공헌을 통한 경영철학 실천

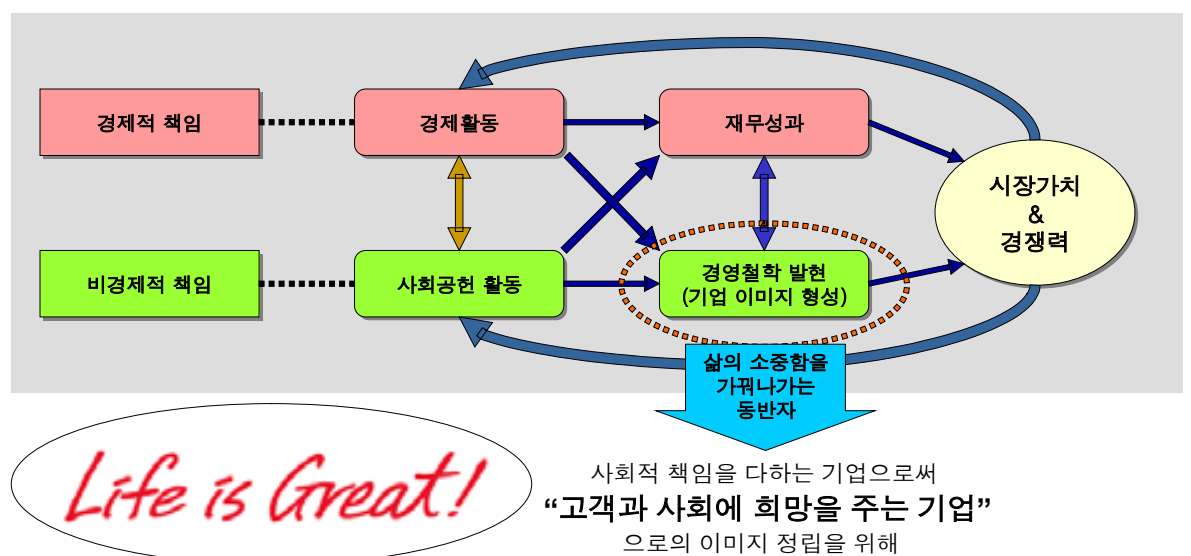

LIG손해보험의 새로운 기업브랜드 전략을 통한 기업이미지 재정립 121 


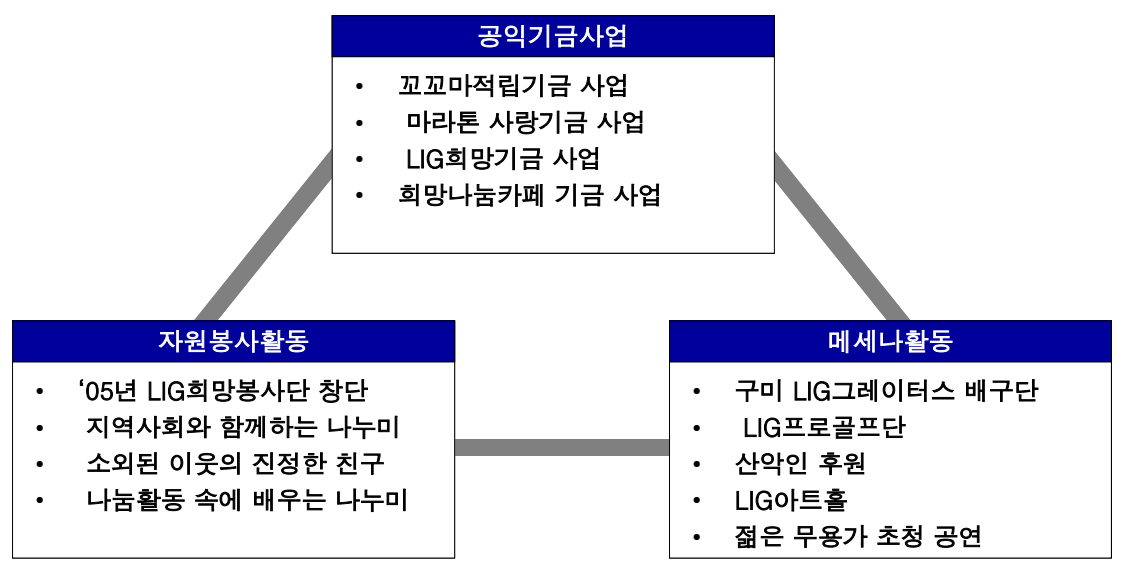

기금을 기반으로 하여 수행되는 공익사업들로 서 꼬꼬마적립기금 사업, 마라톤 사랑기금 사 업, LIG희망기금 사업, 희망나눔카페기금 사업 등이 진행되고 있으며 새로운 사업들을 계획 하고 있다. '꼬꼬마자녀보험’ 공익기금 사업은 2002년 5월부터 수입보험료의 $0.5 \%$ 를 공익기금 으로 조성하기 시작하여 2002년 12월에 '한국복 지재단'과 '대한적십자사'에 협약식 체결 후 기 금을 출현함으로써 공익기금 사업이 활성화되 기 시작했다. 2007년 말까지 총 8억 9천 만원 기금을 출연하여 "고객과 사회에 희망을 주는 기업”의 이미지 강화를 위한 발판으로써 가정 위탁보호아동 지원을 활성화할 계획이다. 마라 톤 사랑기금 사업은 2004년부터 미터당 $\mathrm{CEO}$ 는 100 원, 임원은 10 원, 직원은 1 원씩 마라톤 기금 을 적립하여 2005년부터 당사 교통사고유자녀 대상으로 기금을 지원해왔고, 보상센터로부터 추천 받은 교통사고 유자녀 7명에게 연간 200 만원씩 기금을 지원하고 있다. 이러한 기금사업 은 임직원들의 마라톤 참여를 독려하게 되어, 마라톤 행사 참여가 활발해 지고 있는 추세이
다. 또한 기업의 기부문화 정착을 위하여 임직 원들의 참여와 회사의 매칭그랜트로 기금을 적 립하여 기부하는 'LIG희망기금'사업 추진을 계 획하고 있다. 'LIG희망기금'사업은 임직원들의 자율적 참여방식으로 기금조성하고 임직원들의 기부금과 동일 액수를 회사에서도 기금을 출연 (매칭트랜트)하여, '소외되고 상처 받은 어리이' 구호를 위한 사업을 전개할 예정이다. '희망나 눔카페 기금'사업은 2007년 4월에 LIG본사건물 1 층에 '희망나눔카페'를 운영하여 음료 한잔 당 1 천원씩을 기름으로 적립하고 있는 사업이다. 이렇게 모아진 기금은 '교통사고유자녀' 돕기에 사용될 예정이다.

$\mathrm{LIG}$ 구성원들의 자발적 참여에 의해 이루어 지는 자원봉사활동은 조직구성원들의 기업에 대한 자긍심형성과 자아실현에 긍정적 영향을 미치는데, LIG손해보험은 지역사회와 함께하는 나누미, 소외된 이웃의 진정한 친구, 나눔활동 속에 배우는 나누미 등의 자원봉사활동을 수행 하며 지속적으로 새로운 자원봉사분야를 개발 하고 있다. 전국적인 봉사조직인 ' $\mathrm{LIG}$ 희망봉사 
단'의 자원봉사활동을 당사 사회공헌사업의 대 표 프로그램으로 추진하고자 계획하고 있다. 'LIG희망봉사단'은 LIG손해보험의 전국 네트워 크를 활용하여 100 여 개의 봉사팀에서 10,000 여 명의 봉사단원이 활동하는 것을 목표로 한다. 지역사회의 복지기관 또는 전문단체와 연계하 여 각 지역의 취약 시설 및 가정을 방문, 나눔 활동을 전개하고 한다. 그리고 일회성, 이벤트 성의 활동을 지양하고, 소외된 이웃이 스스로의 삶을 소중하게 여기고 아름답게 가꿔갈 수 있 도록 도와주는 꾸준한 도우미가 되도록 구상하 고 있다. 형식적인 활동이 아닌, 우리의 노력으 로 이웃에게 실질적인 도움을 줄 수 있는 활동 을 수행하여, 무리하고 거창한 활동보다는 수행 가능하면서 $\mathrm{LIG}$ 가 가지고 있는 능력을 십분 발 휘하여 이웃에게 힘을 보태주는 활동을 전개하 고자 한다.

또한 문화마케팅의 일환으로 수행되는 메세나 활동으로는 구미 $\mathrm{LIG}$ 그레이터스 배구단, $\mathrm{LIG}$ 프 로골프단, 산악인 후원, LIG아트홀, 무용가 초청 공연 등이 있으며, 향후에도 스포츠와 예술 분야 를 적극 지원할 계획이다. 국내 스포츠 후원을 통해 국민 여가 선용에 이바지하고, 산악인 후원 을 통해 사회에 도전정신을 전하고자 한다.

\subsection{LIG손해보험의 비전}

LIG손해보험은 다양한 사회공헌활동을 강화 하며 확고한 기업이미지를 구축하기 위해 노력 하고 있다. 이러한 노력들은 2007년 들어 급격 한 매출증가세로 나타나고 있다. $\mathrm{LIG}$ 손해보험 은 2010년에는 시장점유율 20\%에 매출 6조원 을 목표로 삼은 비전2010을 선포하며 본업인
보험업을 기반으로 종합금융그룹으로 도약하는 성장전략을 세웠다.

지역별 환경을 감안해 차별화된 매출 목표를 수립하였는데, 우량 지역에서는 시장점유율 확 대에 주력하고, 비우량 지역에서는 수익창출 기 반을 조성하는 데 중점을 두는 방식이다. 또한, 사업 다각화를 위해 퇴직연금시장, 민영 건강보 험 및 모기지보험 등 새로운 시장을 적극 모색 하고 있다. 날로 중요해지는 해외보험 사업기반 강화를 위해 중국과 베트남 보험시장을 적극 공략한다는 구상도 갖고 있다. 그리고 2010년까 지 종합금융서비스 체제를 구축해 일등 보험금 융그룹으로 성장하기 위해, 다양한 금융사업에 진출하며 금융기관 네트워크화를 추진하는 방 안도 모색 중이다.

$\mathrm{LIG}$ 손해보험은 최근의 높은 경영성과를 기반 으로, 경제활동으로 재무성과를 거두는 경제적 책임과 사회공헌활동을 통한 비경제적 책임을 함께 짊어지고 나아갈 때, 진정한 "고객과 사회 에 희망을 주는 기업”으로 소비자들의 마음속 에 새길 수 있음을 확인할 수 있었다. 이들이 기업브랜드 교체라는 어려운 과제를 해결하며 추진해 온 기업이미지구축전략은 향후 비전 2010 달성의 원동력으로 작용하게 될 것이다.

〈논문 접수일: 2008. 09. 30〉 〈게재 확정일: 2008. 09. 30〉

\section{참고문헌}

경향신문, “급변하는 시장환경서 새롭게 도약" LIG 손해보험 새 CI 선포식,” 2006.04.05. 
동아일보, "LIG손해보험 제2창업 선언," 2006. 04.04 .

매일경제, "방카슈랑스 1위 발판 종합보험그룹

시동," 2006.03.03

문화일보, “'LIG 손해보험” 으로 사명 변경 -새

로고 걸맞는 새 분야 개척,” 2006.02.21

서울신문, "한글 $\rightarrow$ 영문 이니셜 $\rightarrow$ 아이콘으로 진

화하는 CI," 2006.02.23.

안광호, 하영원, 박흥수(2004), 마케팅원론, 학 현사.

오세조, 박충환, 김동훈(2005), “고객중심과 시 너지 극대화를 위한 마케팅원론, 박영사. 최인혁, 김화동(2000), “경쟁적 가치 관점에서

본 기업아이덴티티의 구성요소," 경영학연 구, 29권 3호 pp429-450.

헤럴드경제, "LIG손해보험, 사명 변경 이후 첫 신상품 출시,” 2006.04.05.

Balmer J, Greyser S.(2006), "Integrating corporate identity, corporate branding, corporate com- munications, corporate image and corporate reputation," European Journal of Marketing, Vol. 40, pp730-741.

Balmer J. (2001), “Corporate identity, corporate branding and corporate marketing - Seeing through the fog," European Journal of Marketing, Vol. 35, pp248-291.

Melewar T, Hussey G, Srivoravilai N.(2005), "Corporate visual identity: The re-branding of France Télécom," Journal of Brand Management, Vol. 12, pp379-394.

Muzellec L, Lambkin M.(2006), "Corporate rebranding: destroying, transferring or creating brand equity?. European Journal of Marketing, Vol. 40, pp803-824.

Karaosmanoglu E, Melewar T.(2006), “Corporate communications, identity and image: A research agenda," Journal of Brand $\mathrm{Ma}^{-}$ nagement, Vol. 14, pp196-206. 


\title{
LIG Corporate Image Re-establishment through New Corporate Image Strategy
}

\author{
Ahn, Kwangho* \\ Yoo, Changjo** \\ Kim, Donghoon***
}

\begin{abstract}
After having changed its corporate brand from LG Fire \& Marine Insurance to LIG Non-life Insurance in 2006, LIG Insurance has successfully built the corporate image as the leading insurance financial group by engaging in extensive corporate social responsibility activities.

LIG, as 'a partner for sharing precious moments of life', intended to provide customers a new value of an insurance by building up the new corporate brand. It established three values to be shared internally. First was to instill a brand value orientation within the organization. Second, the firm identified the brand's value to be delivered to the customers. Third, they defined the image objective to be communicated to them.

Based on these set of objectives, the company designed and implemented an integrated marketing communication(IMC) strategy over several years. The result was a successful transition to the new corporate brand name.
\end{abstract}

Key words: Non-life Insurance, Corporate Image, Brand Identity, Brand Architecture, Communication, Corporate Identity, Social Responsibility Activity

\footnotetext{
* Professor, School of Business, Inha University

** Professor, School of Business, Dongguk University

*** Professor, School of Business, Yonsei University
} 